Insight, part of a Special Feature on Exploring Feedbacks in Coupled Human and Natural Systems (CHANS)

\title{
A mixed-methods analysis of social-ecological feedbacks between urbanization and forest persistence
}

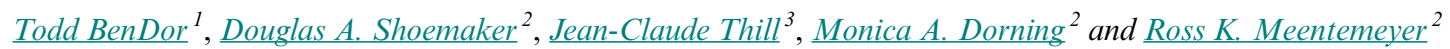

\begin{abstract}
We examined how social-ecological factors in the land-change decision-making process influenced neighboring decisions and trajectories of alternative landscape ecologies. We decomposed individual landowner decisions to conserve or develop forests in the rapidly growing Charlotte, North Carolina, U.S. region, exposing and quantifying the effects of forest quality, and social and cultural dynamics. We tested the hypothesis that the intrinsic value of forest resources, e.g., cultural attachment to land, influence woodland owners' propensity to sell. Data were collected from a sample of urban, nonindustrial private forest (U-NIPF) owners using an individualized survey design that spatially matched land-owner responses to the ecological and timber values of their forest stands. Cluster analysis $(n=126)$ revealed four woodland owner typologies with widely ranging views on the ecosystem, cultural, and historical values of their forests. Classification tree analysis revealed woodland owners' willingness to sell was characterized by nonlinear, interactive factors, including sense of place values regarding the retention of native vegetation, the size of forest holdings, their connectedness to nature, 'pressure' from surrounding development, and behavioral patterns, such as how often landowners visit their land. Several ecological values and economic factors were not found to figure in the decision to retain forests. Our study design is unique in that we address metropolitan forest persistence across urban-rural and population gradients using a unique individualized survey design that richly contextualizes survey responses. Understanding the interplay between policies and landowner behavior can also help resource managers to better manage and promote forest persistence. Given the region's paucity of policy tools to manage the type and amount of development, the mosaic of land cover the region currently enjoys is far from stable.
\end{abstract}

Key Words: forest persistence; land-use change; social-ecological feedbacks; tax policy; urban forests; urbanization

\section{INTRODUCTION}

As urban expansion has accelerated throughout the world, per capita developed land area has expanded (United Nations 2007). By 2030, cities across the developing world are predicted to triple in extent, with an overall reduction in density despite a doubling in population (United Nations 2005). In the United States, an array of recent research has conclusively demonstrated that the conversion of forests and farmlands to low-density built environments has compromised the sustainability and resilience of local ecosystems and the resources they provide (Maestas et al. 2003, Brown et al. 2005, Hansen et al. 2005, Radeloff et al. 2005, Berke et al. 2006), as well as made urban areas more ecologically homogeneous (Pickett et al. 2011). Moreover, the weak networks of forests and farmlands, which persist along urban-exurban gradients, have become increasingly fragmented, with compromised ecosystem function as compared to their bucolic counterparts. Although many American metropolitan regions are actively planning future growth patterns, these effects appear to be accelerating with little sign of embracing alternative futures for urban growth (Ewing et al. 2002).

Nonetheless, remnant forest patches, which pattern the landscape, continue to be valued as vital repositories of cultural practice, refuges of natural heritage and biodiversity, and essential providers of clean air, water, and open space (McDonnell and Pickett 1990, Bolund and Hunhammar 1999). For many city and suburban dwellers, the presence of urban forests and undeveloped spaces provides an essential quality of life component (Bolund and Hunhammar 1999, Chiesura 2004, Tyrväinen et al. 2007).

Despite these vital functions, surprisingly little is known about the social-ecological factors influencing the persistence of forests across urbanizing regions. Over half of the woodlands in the rapidly urbanizing southeastern United States are nonindustrial private forests (NIPF) owned by individuals and families whose attitudes and motivations toward the natural services their lands produce are not well understood (Butler and Leatherberry 2004). Nonindustrial private forest owner attitudes, particularly those that influence the decision to hold or convert forests at the frontier of urban expansion, have far reaching consequences in the Charlotte (NC) region. Better understood are the powerful demographic, technological, and economic forces driving the conversions of greenfields to development (Ewing et al. 2002). These conversions grow and give structure to cities (Anas et al. 1998, Glaeser and Kohlhase 2004) and are the subject of numerous fields of study, including urban economics, urban geography, and regional science.

Given that urbanization continues to expand, researchers are now calling for multidisciplinary approaches capable of bridging contemporary urbanization studies with ecology to inform the planning and management of rapidly changing urban ecological systems (DeFries et al. 2012). We present several findings of a National Science Foundation Urban Long Term Research Area (ULTRA-Ex) exploratory project aimed at studying the persistence of forests in the Charlotte metropolitan region of North Carolina (USA), an example of the numerous, rapidly urbanizing regions throughout the United States.

We used a mixed methods approach to examine the feedbacks between forest attributes, landscape configuration, cultural dynamics, such as woodland owner environmental attitudes and sense of place, and forest policy incentives to better understand landowner decision-making processes from which landscape structure emerges. By focusing on the proximal issue of site-level forest conversion, we hoped to understand whether the observed persistence of urban forests is a cultural quirk or instead suggests a dynamic equilibrium of land covers. We tested the hypothesis 
that private landowner's predilection to sell forest in the region is primarily conditioned by a combination of human and ecological intrinsic values that are not well represented by economic factors.

Nonmarket values have been notoriously difficult to represent in natural resource and environmental economics. Our study design is unique in that we addressed metropolitan forest persistence across urban-rural and population gradients using a unique individualized survey design that richly contextualized survey responses. To provide the necessary data, we developed and administered a novel survey of woodland landowners along an urban gradient (an understudied population), collecting both site and general data on owner's decision-making processes and familiarity with their land, awareness of invasive plants, forestrelated revenues, market values, and predilection to sell. Evaluation of household economic utility and land markets is beyond the scope of this study. These survey data were spatially matched with the concurrent findings of a rapid biological assessment, which included a 'timber cruise' that estimated the market value of standing timber on site. Finally, site-level landscape context variables were generated from concurrent and historical multispectral and aerial remote sensing data. We statistically leveraged these rich data to reveal complex and often nonlinear relationships between the land, the landscape, values, and the woodland owner's willingness to sell.

\section{BACKGROUND}

\section{Combining urban ecology and land-use conversion research}

A vast literature comprising work in multiple fields has established useful frameworks for understanding and studying land-use change decisions and ensuing urban growth (Agarwal et al. 2002, Schaldach and Priess 2008, Irwin et al. 2009, BenDor et al. 2011). We extended the framing of this process from an amalgamation of economic, ecological, and urban planning perspectives, whereby extant patterns of human settlement are the product of a series of individual land-conversion decisions that combine to produce large scale and long-lasting impacts affecting society and environment.

Patches of natural land covers are known to provide a range of ecosystem services, which support human well-being. In southeastern landscapes, the fundamental unit of change and ownership attributed to human agency is the parcel, and at the intersection of parcel ownership patterns and natural patches are woodland holdings, which generate provisioning, regulating, and supporting services. The decision to convert or retain these holdings is therefore the fundamental process generating landscape patterns and altering ecosystem function. The decision itself is dependent on a hierarchy of factors, and methods to evaluate place-based decision making are widely studied and include location choice theory (Isard 1956), game theory (Fudenberg and Tirole 1983), and analyses of public commons (Ostrom 1990).

Neoliberal economic theory allows markets to appropriate land rent values; although nonmarket valuation has been studied for decades (Hotelling 1947, Mathis et al. 2003), only recently have nonmarket or 'missing market' land values come under examination in the context of social-ecological systems. Foremost are value equivalency approaches, which capture many otherwise missing markets such as water filtration and carbon sequestration.
Developed in the field of ecological economics (Costanza et al. 1997, Daily 1997, MEA 2005), willingness to pay (WTP) valuations have facilitated the use of ecosystem service and natural capital inputs within economic, utilitarian-based, decision-making frameworks, such as cost-benefit analysis (CBA). However there are significant shortcomings to value-equivalency approaches. Foremost is the difficulty in monetizing cultural values likely to influence landowner behavior.

In areas of market-driven and uneven growth, the persistence of individual forest remnants behind the urban frontier may be manifestations of (1) market timing, (2) landowner resistance, or (3) alternative valuations of 'highest and best use' (HBU; Dotzour et al. 1990) that explicitly consider nature's benefits beyond economic utility, thereby creating resistance to conversion. At regional scales, this translates into resilience of urban forest systems. If the third case is correct, the prevalence of utility functions, which incorporate individual and ecological intrinsic values, is a significant amendment to the rational economic determinism thought to drive urban land consumption pattern and likely indicates influential feedbacks between people and the environment not captured by HBU as typically understood.

Despite significant effort, studies have yet to yield a comprehensive understanding of the hierarchical and cascading factors describing the dynamic interactions and feedbacks between the institutions, ecosystems, and human agency influencing land development. In the absence of comprehensive mechanisms for retrospective and predictive analysis of these factors, decision makers and the resulting land-use policy are often left poorly informed and lacking alternatives.

Evidence now suggests that land-use policies created in this vacuum are inadequate for managing sustainable growth and lack effective incentive systems necessary for affecting change (Berke et al. 2006, BenDor and Doyle 2009). When we consider the tools/models informing these policies, it is also important to observe that, as modern land-use change models have become more technically sophisticated, few incorporate much of the behavioral richness that is at the core of microlevel social and economic decision processes. This has become an important factor limiting improvements in models' theoretical and empirical capacity (Westervelt et al. 2011).

To better understand complex social-ecological systems, integrative analyses are critically needed to bridge the common disconnect between micro and macro approaches in human-environment interaction studies (Naveh 2000, Holling et al. 2002, NSF 2003, Warren 2005). Although 'macrostructural' approaches are often criticized for ignoring human subjectivity and agency, Scoones (1999:493) argued that the microlevel studies, which dominate social-ecological research, fail to fully contextualize the "institutional and political processes that mediate the relationship between agency and structure across multiple scales in the process of environmental and social change."

Moreover, social, economic, and political processes are not typically coupled closely with ecological system dynamics. Ecological settings are heterogeneous, dynamic systems that are iteratively mediated by nonlinear, nondeterministic biophysical forces that interact dynamically with socioeconomic processes. Scoones (1999:490) urged the development of innovative approaches that "link dynamic structural analysis of environmental processes with an appreciation 
of human agency in environmental transformation, as part of a 'structuration' approach."

Viewing these approaches in the face of calls for multiscalar, interdisciplinary perspectives on social-ecological problems (Pickett et al. 1997, Zipperer et al. 2000), suggests the need for a synthesis of structuration theory from sociology (Giddens 1986) and hierarchy theory from ecology (Pattee 1973, Allen and Hoekstra 1993). This synthesis conceptually bridges ecological and institutional processes, while also taking into account links between local ecological factors and microlevel sociological analysis of individual decisions regarding land use (Warren 2005). Mirroring this, the emerging field of 'sustainability science,' which integrates ecosystem and institutional process evaluation at multiple scales, also increasingly requires conceptual frameworks and analytical methods that foster the sharing of biosocial vocabularies and measures (Grove and Burch 1997).

\section{Analysis of decisions affecting forest persistence}

To construct a multilevel framework for understanding feedbacks between societal and ecological factors that influence persistence and quality of forest, we introduce two competing hypotheses:

(1) Forest landowner's willingness to sell is primarily predicated on housing rent and land concessions and/or timber revenues meeting or exceeding the perceived development value of the land. Landowners are less willing to sell when revenues meet or exceed the perceived development value of the land.

(2) Woodland's ecological assets, such as forest quality, biodiversity, or prevalence of charismatic tree species influence owners' willingness to sell. Conversely, the presence of noxious invasive vines and shrubs are a disincentive to forest persistence.

There is a hierarchy of interconnected factors that affect the ecological and human intrinsic, extrinsic, and development values of forested landscapes along an urban-exurban gradient. Our first hypothesis is based on basic microeconomic theory, which posits that rational individuals make utility maximizing decisions (Salvatore 2008). However, we commonly observe forest persistence despite development value exceeding forest product revenues, i.e., extrinsic value. In this case, classic microeconomic theory suggests that a landowner's land utility additionally incorporates the nonmonetary, ecological, and nonecological value imputed to land for its own sake, i.e., intrinsic value, which is mediated by a combination of multilevel structured values (Wang and Wolverton 2002). This intrinsic value of land is grounded in (1) ecological characteristics of the land, such as forest and soil quality, diversity of plant species, and the prevalence of invasive species (Farber et al. 2002, Polasky et al. 2005), as well as (2) in human dimensions, such as personal experiences with the land, family heritage, and place-specific symbolism (Pred 1984, Stedman 2003, Williams and Vaske 2003).

It is important to note that intrinsic land valuations are typically subjective and are widely influenced by the ambient culture of the community, e.g., land ethics; policies, e.g., the application of the U.S. Endangered Species Act, state conservation laws, local restrictions on development; and/or natural and built environment geographies, e.g., viewsheds, proximity to roadways. Settlement configuration, i.e. urban form, may also influence forest quality through its effects on (1) patch size and degree of fragmentation, (2) successional stage, and (3) flux of disturbancetolerant invasive species across a landscape.
The extrinsic values of forests are typically indicated in a variety of ways, including markets for forest products and broader economic processes at the national and international scales, which are affected by the geography of natural and built environments, e.g., geographic accessibility, and public policies, e.g., tax credits such as 'present-use valuation' (PUV), whereby qualifying working lands are taxed under current agricultural values, not market values. On the other hand, the value of real estate is largely determined by its access to amenities, including those that are natural, transportation corridors, employment, and other forms of development. These factors, modulated by higher level market forces, exert development pressure in the form of rising land values on undeveloped lands, particularly on remnant forests at the frontier of urbanization.

\section{STUDY AREA}

This study is directed at the metropolitan region surrounding Charlotte, North Carolina (Fig. 1). The six-county study area is located within the Piedmont physiographic province at the foot of the Blue Ridge Mountains and covers 796,489 hectares. Best known for its bucolic natural and agricultural landscapes, Charlotte is also part of the rapidly growing 'Char-lanta' megalopolis, the third largest mega-region in the U.S., sprawling from Raleigh, North Carolina to Atlanta, Georgia (Florida et al. 2008). We focused our work throughout the urban to rural gradient, radiating from the center of the city, including parts of downtown Charlotte and eastern Mecklenburg County, into five of the counties in the eastern part of the metropolitan region (Iredell, Rowan, Cabarrus, Stanley, and Union counties).

Since the mid-1980s, immigration attributed to climate, strong job markets, and regional amenities has doubled the region's population. These growth and development trends are expected to continue through the recovery from the Great Recession; the 14-county Charlotte-Mecklenburg metropolitan statistical area is expected to grow by $50 \%$ by 2030 , an increase of 1.2 million people (North Carolina State Demographics Office 2011).

During Charlotte's booming growth phase over the last several decades, development has spread across the region in disjoint, with low-density patterns abetted by a dense network of modern highways and few natural barriers to construction. Recent studies of the 'human footprint' in the region revealed the alarming result that per capita land consumption has increased significantly from 1976-2006 and will lead to the additional loss of 280,000 ha of forested and agricultural land by the year 2030 under recent trends (Fig. 2; Meentemeyer et al. 2013).

This period also saw commercial and housing markets expand in response to population growth, the relative lack of planning ordinances, and few physical constraints, leading to increases in urbanized area by nearly $60 \%$ (Meentemeyer et al. 2013). Like other cities in the mega-region, Charlotte has lost, and continues to lose, substantial tree canopy to greenfield development, however a study by American Forests (2010) found that $46 \%$ of Charlotte remains forested with urban canopy, a proportion that compares favorably to Atlanta at 27\% (American Forests 2002), Nashville at 29\% (Graham and Hanou 2010), and Greensboro at $38 \%$ (Cusimano et al. 2009). Pride in Charlotte's recognition as "the City of Trees" lead the city council in 2011 to adopt a tree canopy goal of 50\% by 2050 (Charlotte City Council 2011). 
Fig. 1. The Charlotte Metropolitan region located within (A) the 'Char-lanta' megalopolis in the southeastern United States. (B) The spatially heterogeneous landscape contextualizes woodland owners' experience. In 2011, $38.2 \%$ of the region was forested, $26.5 \%$ was agricultural, $9.8 \%$ developed, $22.3 \%$ managed nonagricultural greenspace, and 3.1\% water. (C) Detail of the study system in which identified nonindustrial private forest holdings (dark outlines) in overlay with the development pressure variable developed for this analysis. Private forests are found widely along the urban gradient, which ranges from red in areas dominated by impervious surfaces, to yellow in undeveloped areas proximal to development, to green in areas distal to development. Program participants were recruited from this group.

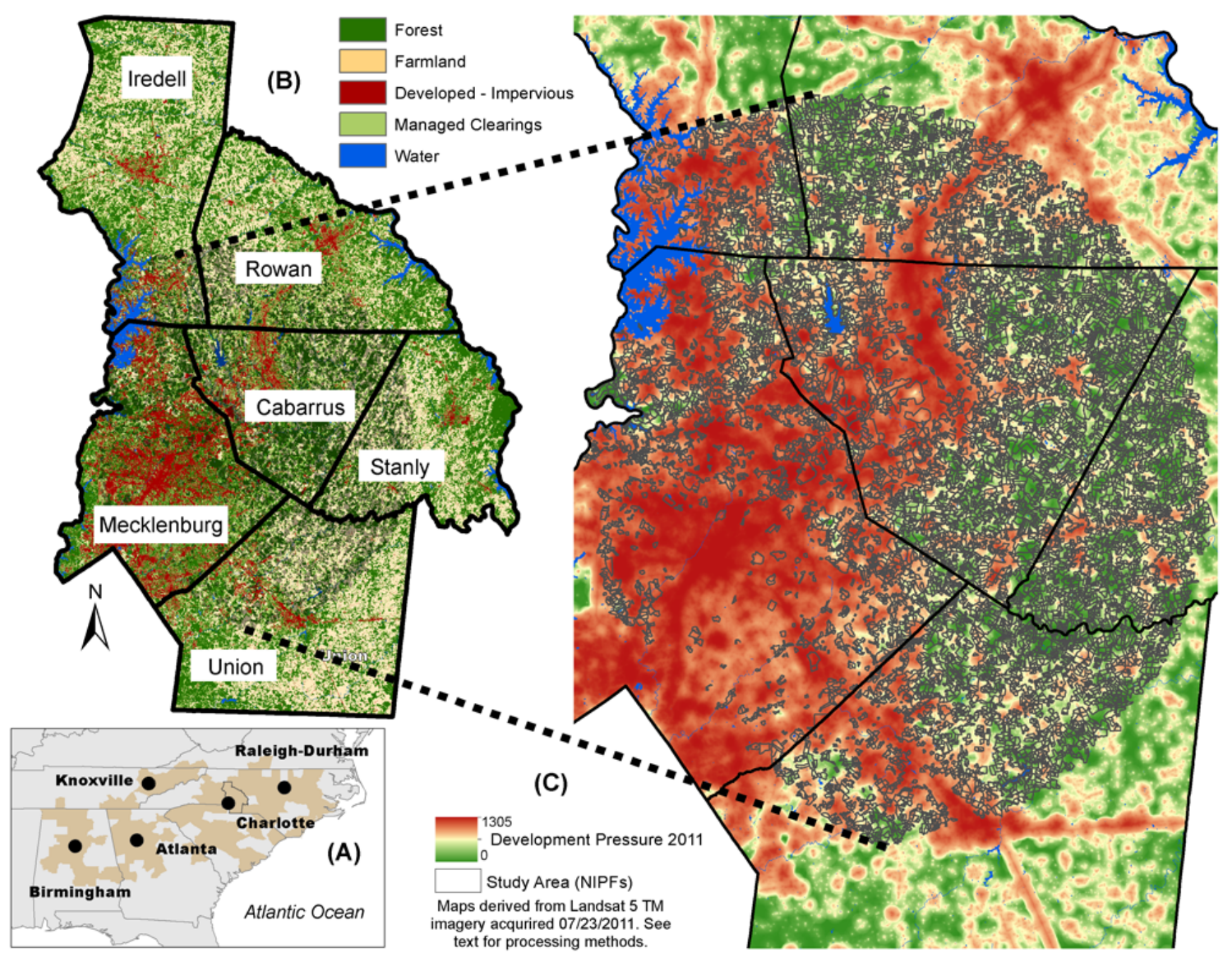

\section{Social and policy setting in the Charlotte region}

Development in Charlotte is the product of a complex socialecological system. Although there appears to be growing interest in open space preservation and green development, the cultural climate in North Carolina remains strongly dedicated to private property rights ideologies. As a result, counties and municipalities regularly employ few planning instruments, including temporary building moratoria, adequate public facility ordinances, and zoning (Ott and Read 2006), with the last being routinely adjusted to landowners' wishes in the face of high development pressure. Furthermore, recent studies suggest that land-use policy in the Charlotte region is inadequate to manage sustainable growth (Sustain Charlotte 2010, Urban Land Institute 2010, 2011).

However, as in many U.S. metropolitan regions, despite a lack of relevant policy and planning mechanisms, there remains sustained demand for open space in Charlotte. Recent evidence shows that public sentiment against unmanaged growth is stronger than ever (CCOG 2011a,b); for example, despite the declining economy, voters in November 2008 voted to issue US $\$ 60$ million in bonds targeted specifically for acquisitions of open space in anticipation of further development in the region (Boraks 2008). Moreover, during this period, Cabarrus County (see Fig. 1) commissioners established a de facto growth boundary by agreeing not to extend city utilities to the rural eastern part of the county.

Recent economic studies suggest the need to understand hierarchical complexities that influence persistence and quality of natural landscapes in Charlotte. For example, econometric analyses now indicate that the presence of open spaces in the Charlotte area, particularly greenways, increases the value of adjacent real estate drastically (Campbell and Monroe 2007). It is estimated that tax revenues in Charlotte-Mecklenburg County will exceed US\$600,000 per annum following the establishment of a proposed Catawba River trail system. However, although public open space acts as a normal good, i.e., positive income elasticity of demand, municipalities in North Carolina 
Fig. 2. Changes in land-use patterns 1996-2011. Development patterns identified in land-cover mapping were aggregated into development intensity classes suggested by Angel and Parent (2007) to illustrate the extent and magnitude of change in the region. Rapid expansion of growth into undeveloped areas prevailed in the region through 2006. Coincident with the Great Recession, expansion after 2006 was reduced and characterized by infill, which aggregated low intensity and fringe development into the higher intensity class.
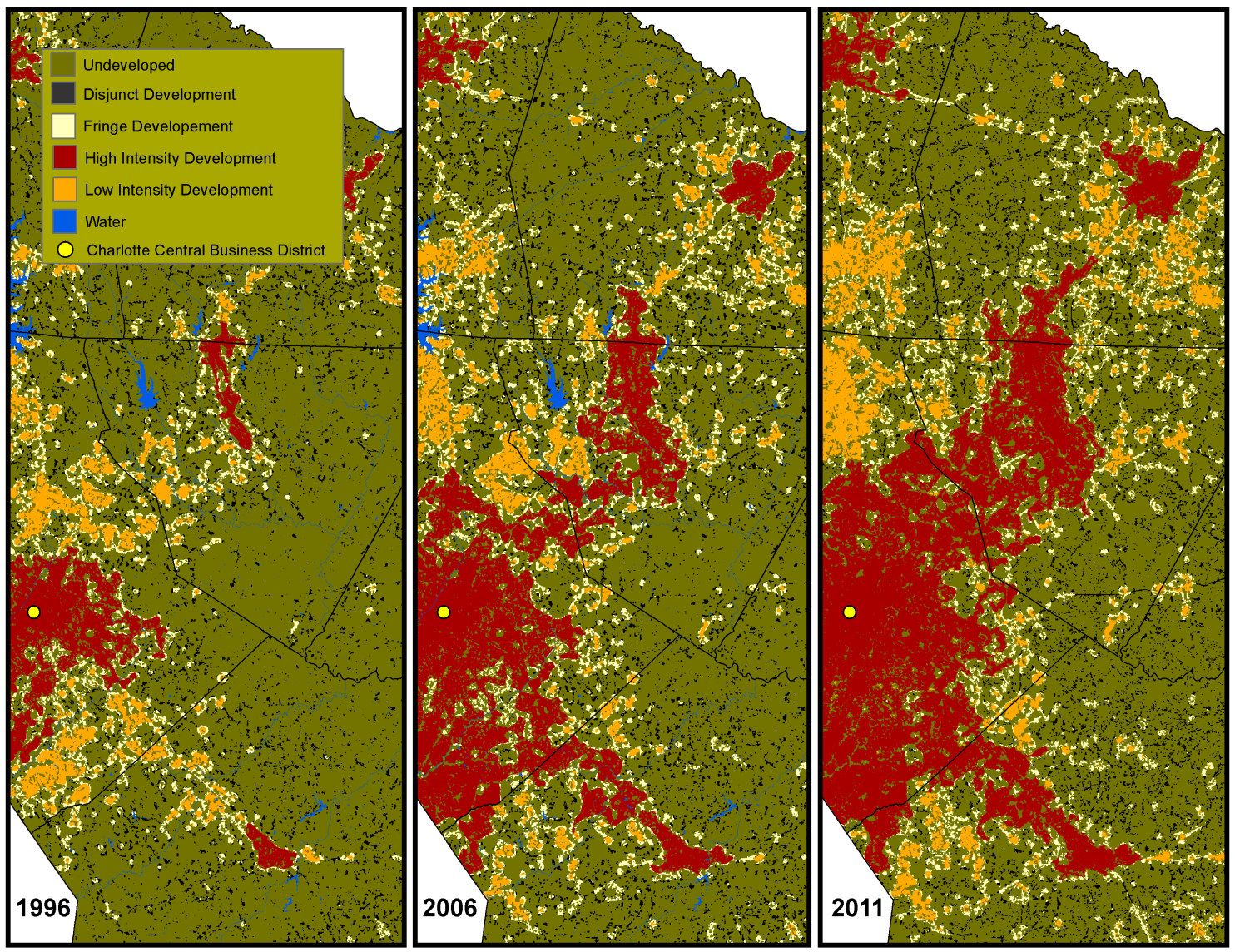

experiencing the most rapid growth tend to have the least open space per capita (Wang et al. 2012).

The geography of urban forests in the Piedmont illustrates an emerging and dynamic urban-ecological complex with substantial forests outside the frontier of development. Woodland owners there are facing accelerating local population growth, increases in land demand and markets, and other factors that affect their use and enjoyment of their land, while simultaneously increasing their opportunities to sell (Chesser 2013, UNC Charlotte Urban Institute 2013). However, their attachment to land and sense of place are shared attitudes and cultural practices, which are deeply rooted in the collective history of local communities. These social constructs have been argued by Havard (1981) to be at the core of Southern culture, i.e., the 'Old South', although recent immigration from other U.S. regions and from overseas has brought conflicting views on these issues, while recentering the debate on environmental conservation in some local communities.

The decision to convert woodland to development is the seminal act from which new landscape patterns emerge, and private landowners must continuously weigh changing markets, policy, and local geographies against the cultural and ecosystem services and amenities provided by their land. Our goal is to examine anthropogenic land transformation in the rapidly urbanizing Charlotte region to reveal dynamic feedbacks that characterize and influence the persistence of private forest holdings.

\section{METHODS}

Human and ecological intrinsic factors affecting decisions surrounding forest persistence are notoriously difficult to quantify in natural resource and environmental economics. We explored the dimensionality leading to decisions that conserve or develop forests in the Charlotte region using data gathered in three complementary approaches. Our study design was unique in that we addressed metropolitan forest persistence across urban-rural and population gradients using a unique individualized survey design, which richly contextualized survey responses.

First, we collected data on individual intrinsic and extrinsic forest values through a revealed preference survey given to landowners, which documented the decision processes for a sample of privately held woodland holdings located across the urban-exurban gradient of the Charlotte metropolitan region. Second, we measured the ecological assets and merchantable lumber values 
of the woodland holdings specified in the revealed preference survey using field plot and parcel surveys. Third, we quantified the landscape context for each woodland holding from the mosaic of regional land covers using remote sensing data and geospatial analysis. Once collected and aggregated, the georeferenced data overlays of landowner responses, biophysical and resource characteristics, and contextualized landscape mapping formed a rich dataset from which to examine factors influencing the persistence or conversion of forests.

\section{Landowner survey}

With funding from a National Science Foundation (NSF) Urban Long Term Research exploratory (ULTRA-EX) grant and guidance from a coordinated group of community partners, i.e., local organizations, including nongovernmental organizations, cooperative extensions, and local governments (see list in acknowledgements section), we developed a revealed preference survey to administer to a sample of NIPF owners along an urban to rural gradient. The region of interest ranged from uptown Charlotte, i.e., the city center city, into five counties in the eastern part of the metropolitan region (see Fig. 1). This extent was selected to include a balanced population of urban and rural NIPF owners with a minimum of 2 ha (about 5 acres) of contiguous forestlands, primarily mixed evergreen-deciduous and pine plantation types. In anticipation of a site-based forest assessment, a two hectare minimum was chosen to ensure a focus on forests rather than clusters of trees within landscaped areas and to minimize ecological edge effects (McDonald and Urban 2006). We located qualifying woodland owners using an overlay of regional forest canopy (details below) and public parcel data within a GIS. Addresses were extracted from the parcel data and 2500 invitations to participate were mailed using the program pseudonym "Piedmont Landscapes in Transition," a move recommended by stakeholders to counter perceived antigovernment sentiment. Signed consent forms were required before admittance into the program, this was followed by disclosure of the project's scope, identity of the research group, potential harms, and guarantee of confidentiality; the document also granted access to lands to conduct an ecological assessment and timber cruise. In return, participants were provided a summary of ecological assets found on site, an estimate of the value of their standing timber, and a US\$10 gift card to a local hardware store.

Admitted woodland owners were then mailed the 47-question revealed preference survey, which included a map of their holdings for clarity, and asked to report their management motivations and objectives over the previous 24 months for the specific woodland highlighted on the map. Like the National Woodland Owner Survey (NWOS), we used the term 'woodlands' instead of 'forest' or other terms to refer to the forested portion of the NIPF's property (Butler and Leatherberry 2004, U.S. Forest Service 2012a). Questions probed:

- The nature of the individual or party that makes management decisions;

- Acquisition, tenure and annual visitation;
- Management practices;

- Participation in incentive/conservation programs;

- Importance of factors leading to the decision to keep or sell;

- Estimated land and timber value; and

- Land and timber revenues.

Additionally, specific questions within the survey assessed woodland owner's attitudes toward forest values in general, sense of place factors associated with the specified forest holding, and connectedness to nature (Appendix 1).

To explore the diversity of NIPF owner's attitudes and inform us on the degree of sampling bias exhibited caused by self-selection, we asked participants to respond to statements modeled after Brown et al. (2002), "I value wooded lands because...," presenting them with a selection of benefits of possible importance, including aesthetics, provisioning, recreational opportunities, supporting and sustaining services, biodiversity, spiritual, historical, and therapeutic. Responses that clustered around specific attitudes would reveal the directionality and magnitude of the sample's biases, whereas evenness or balancing of clusters would have been indicative of a representative range of values.

Landowner attitudinal typologies were categorized in two steps following methods recommended by Majumdar et al. (2008) using SPSS statistical software version 21.0 (IBM Corporation 2012). First, the dimensionality of response was reduced and transformed using principal component analysis (PCA) with varimax rotation. Second, exploratory analysis using Ward's minimum variance method was used to determine the number of clusters that would effectively capture the range of homogeneity in woodland owners' values. Saturation of cubic clustering criterion values was used to estimate an appropriate number (Sarle 1983). We then used component scores to cluster landowners into nonhierarchal typologies using a k-means method. Similar approaches have been used to categorize woodland owner motivations in the southeastern United States (Majumdar et al. 2008). To develop response data for willingness to sell modeling (see below), the Likert-type scoring used by respondents set endpoints only, e.g., complete disagreement, complete agreement, and therefore was treated as equal interval data. In hypothesis testing, these scores populated predictor variables (listed and described in Appendix 1).

To assess the multidimensional concept 'sense of place,' we modified a survey used by Jorgenson and Stedman (2006) and allowed participants to report their level of agreement to a series of statements about their forest holdings and local development. The survey generated attitudinal variables addressing forests, natural vegetation and development, as well as primary constructs of identity, attachment, and dependence (Jorgensen and Stedman 2001, 2006; Appendix 1). Like forest attitudinal values, the senseof-place data was Likert-type and assumed to be equal interval. We used PCA to condense multiple variable responses into factor 
scores for hypothesis testing. Variables generated included 'attachment,' 'dependency,' 'identity,' 'attitudes about woodland, ' 'attitudes about retaining native vegetation,' and 'attitudes about development' (Appendix 1).

\section{Ecological field data}

To better understand individual forest fragment quality, we developed a forest assessment protocol based on both standard market measurement techniques and the U.S. Forest Service's Forest Inventory Analysis (FIA; U.S. Forest Service 2012b) protocols whenever possible. Data were collected from the same forest remnants specified in the revealed preference survey and included timber volumes for estimates of merchantable assets and biomass, measures of native woody plant diversity, and cover estimates of invasive plants. Subplots measured tree recruitment, soil conditions, and the abundance of invasive woody plants and vines.

For each of the forested holdings surveyed, we established 3-10 0.04 ha circular plots and measured the diameter at breast height (DBH, or stem diameter at $1.4 \mathrm{~m}$ ) of all native and invasive woody plants greater than $12.7 \mathrm{~cm} \mathrm{DBH}$, including vines. Plots were located to avoid borders with other land covers, e.g., agricultural fields, at a density ranging from 0.8 to 1.25 plots per ha. Core samples taken from dominant or codominant trees in each plot were used to estimate maximum age of stand, and source of regeneration was assessed from stem type and configuration within the plot. From these data, we calculated (1) the richness of native and nonnative trees, woody stem shrub, and vine species, (2) the combined biomass of overstory and understory trees using established protocols (U.S. Forest Service 1996), and (3) the gradient of abundance between the region's charismatic and marketable genera Quercus and Pinus.

\section{Forest extrinsic value}

The market value of standing timber in assessed holdings was evaluated by first estimating stand-level dimensional weight using GIS and then multiplying resultant weights by stumpage prices specific to species and intended product (i.e., pulp production or saw timber). This stumpage value method considers species, size, and quality of harvestable trees, as well as implied extraction and transportation costs (United Nations et al. 2005). Within a GIS, we conducted a linear extrapolation of plot-level dimensional volumes to stand-level based using area and forest cover types determined in our mapping of the region (see below). The value of forest products in the southern Piedmont depends primarily on demands from the home building industry, furniture industry, and the pulp and paper market (NCIOF and NCFA 2003), and valuation was based on market prices at time of survey (Harris et al. 2011).

\section{Landscape context and the development of spatial variables}

\section{Regional mapping 1996-2011}

Base data about the local and regional landscapes occupied by NIPFs were drawn primarily from biophysical remote sensing data. We mapped forest canopy and settlement patterns in the region between 1996 and 2011 through analysis of historical Landsat satellite imagery. Using vegetation impervious-surface soil (VIS) processing of leaf-on Landsat satellite images (Lee and Lanthrop 2005, Gluch and Ridd 2010, Meentemeyer et al. 2013), we classified imagery from 1996, 2006, and 2011 into a schema designed for the region, which included developed, agricultural, forested, and disturbed but vegetated 'managed clearing' categories at a resolution of 0.09 ha (Singh et al. 2012). Overall classification accuracies for 1996, 2006, and 2011 map products were $84 \%, 84 \%$, and $90 \%$, respectively. For our participant woodland owner stands, we additionally mapped forest cover types photo-interpreted from 2010 National Agriculture Imagery Program (NAIP) imagery at a minimum mapping unit of $4 \mathrm{~m}^{2}$.

Development of spatial variables

In anticipation of modeling the influence of hypothesized landscape-oriented predictors on landowners' decisions to sell, we assembled a collection of spatial variables derived from our regional mapping effort, as well as GIS datasets for the region from collaborators and government sources or by in-house development. Using these datasets, we developed a suite of spatial variables (see Appendix 1), which were evaluated statistically for their potential to explain the observed changes in landscape pattern.

If we hypothesized that woodland owners were highly aware of their forest's position within the mosaic of land covers, then they continuously weighed the amenities and disamenities accompanying changes in local geographies against the cultural and ecosystem services values provided by their land. Although the revealed preference survey specifically probed attitudes about development and changing character of rural landscapes, we also looked at the geographic context within two kilometers of participant holdings. For example, proximity to existing development, in particular, has been shown in other studies to be highly suggestive of future forest conversion in the region, with previous studies conceptualizing this dynamic as 'development pressure' or a positive feedback loop, i.e., more development brings more development (Meentemeyer et al. 2013). We hypothesized that recent development, in essence the moment or momentum of the frontier of urbanization, may be significant as well. Development and farm 'pressure' are spatial variables derived from regional maps of landscape configuration (Appendix 1). These variables were used to estimate the influence of surrounding land covers on pixels classified as forest, including those holdings targeted for analysis. In each case, the development pressure on cell $i$ is given bv:

$$
\text { Pressure }_{i}=\sum_{i \in n} \frac{\text { State }_{k}}{d_{i k}^{\alpha}}
$$

in which State $_{k}$ is a binary variable indicating whether the $k^{\text {th }}$ neighboring cell is a converted land category, e.g., developed, farm or recent conversion, (1) or forest (0); $d_{i k}$ is the distance between the $k^{\text {th }}$ neighboring cell and the current cell $i, \alpha$ is a coefficient that controls the influence of distance between neighboring cells and cell $i$; and $n_{i}$ is the number of neighboring cells within a specific range with respect to cell $i$. Assuming that the influence of a neighboring developed cell on the current cell is distance-decayed, the development pressure on an forested cell is a function of neighboring developed cells and the distance between these cells and the cell in question. Another hypothesized predictor, 'momentum,' uses the development pressure algorithm to estimate the influence of new conversions on extant landscapes at specified intervals. In this case, targeted State inputs are cells converted between $t$ and $t+1$. We tested three periods of interest 
Fig. 3. Decision tree model of willingness to sell based on five predictors: (1) sense of place values regarding the retention of native vegetation, (2) size of forest holding, (3) development pressure, (4) visitation frequency, and (5) connectedness to nature. Rectangles represent predictions at terminal nodes with the estimated number of woodland owners classified as willing to sell (percentages in parentheses). Critical thresholds on which woodland owners are partitioned are displayed between node connections, and the numbers of woodland owners eligible to split are in blue. This graphic representation of hierarchical and nonlinear relationships between predictors and individual's willingness to sell reveal pathways to woodland persistence in green, where woodland owners are less likely to sell, and paths leading to a willingness to sell in red.

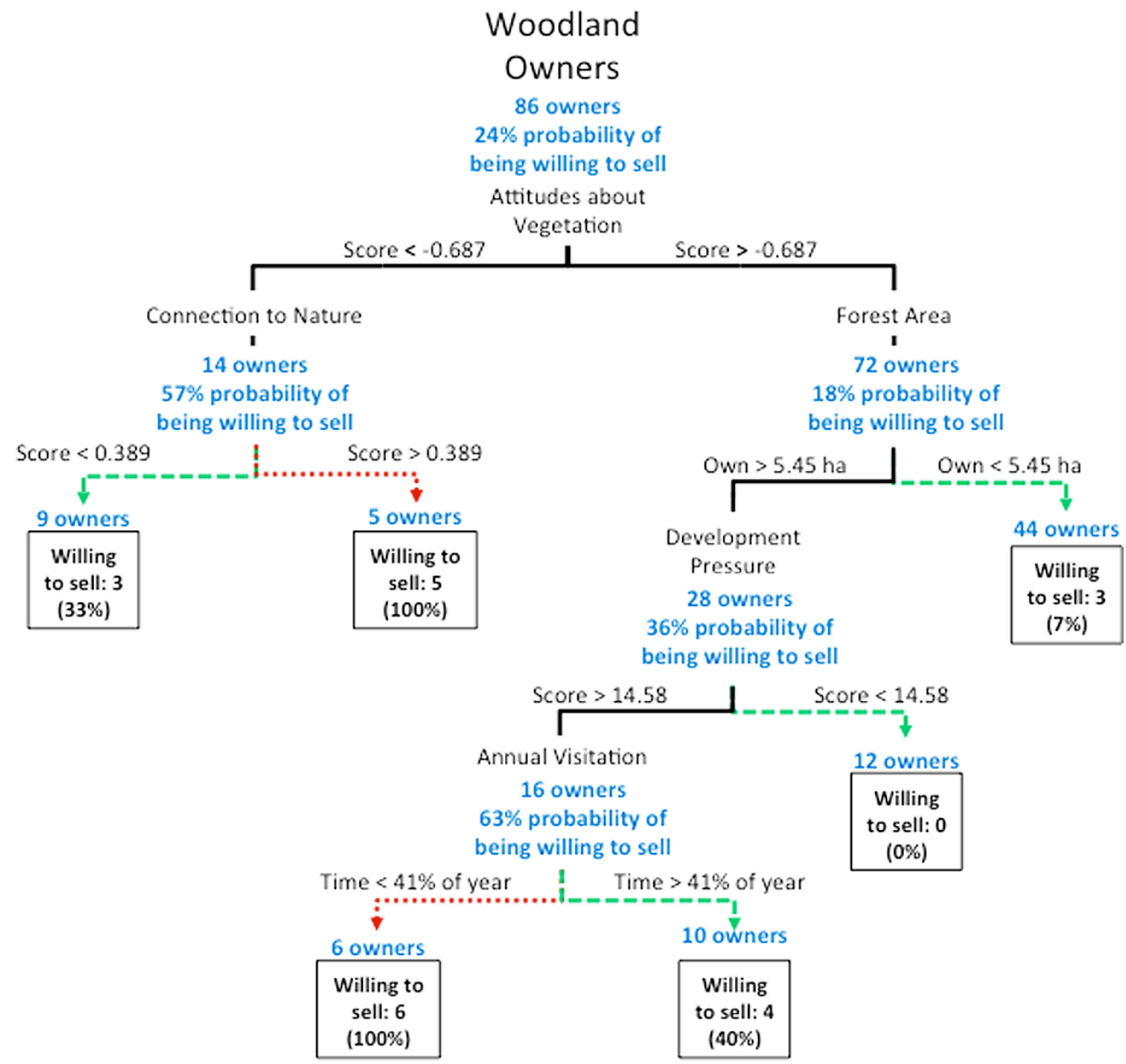

identified in the historical mapping: 1996 to 2006, a period of rapid growth; 2006 to 2011 , a period roughly coincident with the Great Recession; and 1996-2011, the entire study period.

\section{Decision tree analysis and willingness to sell modeling}

We used decision tree models to test our hypotheses and explored the relationship between willingness to sell and 51 intrinsic and extrinsic variables developed from the revealed preference survey, ecological assessment, and landscape context analysis (see Appendix 1). Decision and classification trees are a nonparametric approach to exploring complex systems (Davidson et al. 2009, Hein et al. 2011) and provide an alternative to generalized linear models (GLM) because of their ability to characterize hierarchical and nonlinear relationships and expose interactions among predictor variables (Michaelsen et al. 1994).
Decision tree models were fit using JMP statistical software (SAS Institute 2012) by recursively partitioning a response variable into increasingly homogeneous subsets based on critical thresholds in continuous or categorical predictor variables. The tree-based models could then be graphically displayed so that a progression of binary splits on the independent variables leads to a prediction at the end node (see Fig. 3). The predicted value at each end node is the mean value of all observations that flow through the tree to that node.

A K-fold cross-validation process was used to assess the predictive ability of the model. K-Fold cross validation randomly partitions the original data into $K$ subsets ( $\mathrm{K}=10$, where $90 \%$ of the data was used for training and $10 \%$ for testing), where each of the $K$ subsets is used to validate the model fit on the rest of the data 
(fitting a total of $K$ models). The model giving the best validation statistic is chosen as the final model. This method is recommended for small data sets, because it makes efficient use of limited amounts of data (Michaelsen et al. 1994). The developed tree model was 'pruned' to a parsimonious solution that maximized $\mathrm{R}^{2}$ and classification accuracy (also using JMP statistical software).

\section{RESULTS}

\section{Regional analysis}

Our remote sensing analysis of the study area as a whole revealed that nonindustrial private forest (NIPF) owners control a total of 53,592 ha or $38.7 \%$ of all forests in the study area and $14.3 \%$ of the total nonwater landscape (see Fig. 4). These forests comprise almost 8000 holdings with a mean size of 6.7 ha (16.6 acres). The reliability of these estimates varies by county, as data on legal ownership characteristics are not evenly reported, and private timber sales, indicative of revenue streams, are not public information. Given this caveat, we estimated that $78 \%$ of stands held by NIPFs in 2011 were under 8.3 ha ( 20 acres) and thus not eligible for the State's primary forest incentive plan, 'present-use valuation' (Fig. 5), which the North Carolina Department of Revenue (2014:3) defined as: “...the value of land in its current use as agricultural land, horticultural land, or forestland based solely on its ability to produce income and assuming an average level of management. Property that qualifies for present-use value classification is assessed at its present-use value rather than its market value."

Fig. 4. Regional distribution of nonindustrial private forest stand size. Overlay analysis of regional land cover maps (Fig. 1) intersected with parcel and tax data estimated 53,592 ha $(38.7 \%)$ of all forests in the study area controlled by nonindustrial private forest (NIPF) owners. NIPF holdings comprise almost 8000 stands with a mean size of 6.7 ha $(16.6$ acres). Nearly $78 \%$ of stands held by NIPFs in 2011 were under 8.3 ha (20 acres), and thus not eligible for the state's primary forest incentive plan, 'present-use valuation' (PUV).

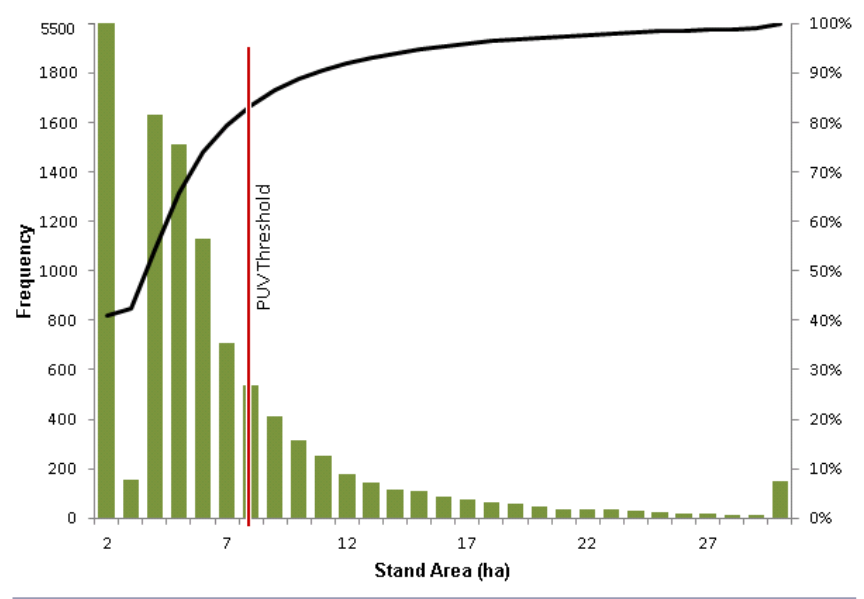

\section{Analysis of participant network}

We received 143 consent agreements to participate in the program, yielding a response rate of $5.7 \%$. This low response rate may reflect antigovernment sentiments in the region, as well as the fact that the study consent involved agreements to participate in two surveys and to grant access to researchers to visit and assess their land. Ultimately, 126 woodland owners completed and returned the revealed preference survey. Of these, 86 received ecological field assessments within 6 months of receiving the survey, leaving 40 without assessment because of logistical limitations. Stands receiving the ecological field assessment were smaller (7.4 ha) compared to the sample of 126 (10.8 ha), but larger than the region as a whole (6.7 ha), and $39.5 \%$ were part of a larger farm or ranch.

Although settlement patterns in the region are polycentric (Fig. 3), the locations of participant stands did exhibit geographically based tendencies. Few participants were found near Charlotte's central core. As was expected, stands closer to Charlotte's central business district (CBD) were smaller on average and experienced more development pressure than larger stands further from the urban core (Fig. 5). Stand size increased in areas of lower development pressure, which tended to be further from the CBD.

Fig. 5. Location of program participants along urban-rural gradient. Basic trends indicate that participants hold a wider range of stand sizes and experience reduced development pressure, with increasing distance from Charlotte's central business district (CBD). However, stand size and development pressure do not increase monotonically with distance, but instead widely overlap indicating the range of landscape context captured by a sample located among heterogeneous development patterns and behind the frontier of development. For comparison purposes, the development pressure threshold identified in decision tree analysis is red cross-hatched.

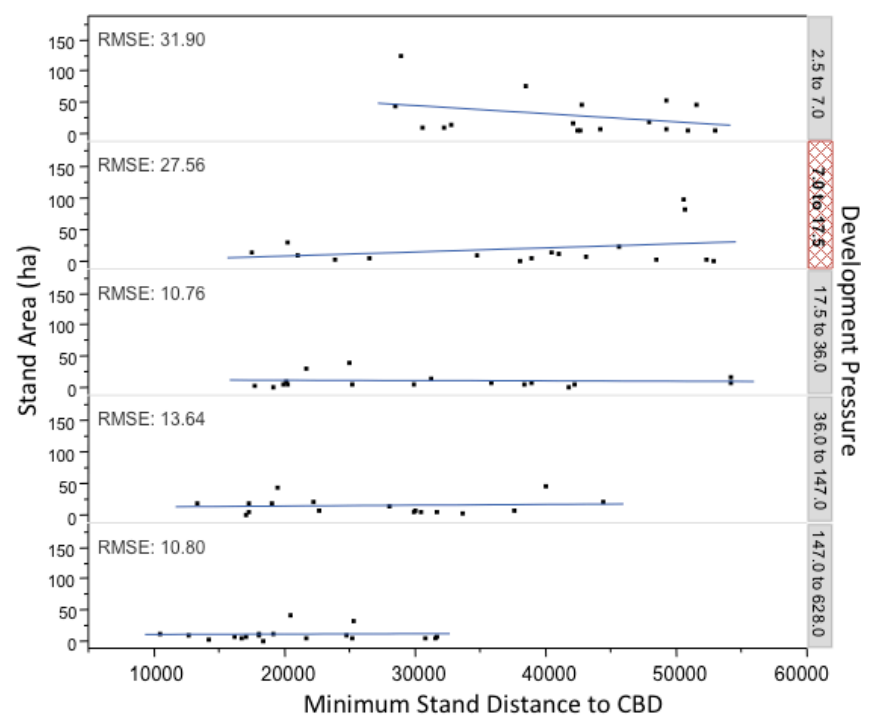


Regional mapping revealed that conversions of forested and agricultural lands to development slowed dramatically from the 1996-2006 peak period, most likely in response to the 2008 economic downturn. On average, 11.1 ha were converted annually within an $800 \mathrm{~m}$ distance, containing a $2 \mathrm{~km}^{2}$ moving window, from forest stand centers. This dropped to 1.0 ha annually between 2006 and 2011. Despite this decline in spatial growth, largely caused by shifts toward apartment and condominium development, immigration into the region has continued, increasing the population in the six counties by $64,387(5 \%)$ between 2006 and 2011 (North Carolina State Demographics Office 2011), perhaps indicating a latent demand for development that may emerge with economic recovery.

The majority of study participants were white $(99 \%)$ and male $(67 \%)$ with a mean age of 64 and mean land tenure of 24 years. These data are consistent with national data from the NWOS (Butler et al. 2007). However, the sample exceeds NWOS national averages in degree of education completed, i.e., $23.4 \%$ with graduate education or higher within the Charlotte region, and in average household income, i.e., US\$140,000 in our study area vs. US $\$ 100,000$ nationally, perhaps reflecting broad socioeconomic effects associated with proximity to a major city (Glaeser et al. 1995). Stands ranged from 2 ha ( 5 acres) to 78 ha (193 acres), with a mean of 10.8 ha (26.7 acres) and a median of 6.3 ha (15.68 acres) and on average, woodland owners controlled three stands that were each greater than 2.0 ha.

We asked participants to estimate the cash value of their land with standing timber, without timber, and to estimate the cash value of their timber only. A small subset of woodland owners estimated the combined land and timber value of their land at US\$83,569 per hectare ( $n=23, s d$ US\$86,726), and land only at US\$48, 185 per hectare $(n=5$, sd US\$49,989). As basis for comparison, industrial timberland sales in the Southeast averaged less than US\$5000 per hectare in 2000-2010 (Harris et al. 2011). For this study, we did not estimate the development value of participant land holdings. Limited data collected from woodland owners $(n=2)$ found that they valued their standing timber at an average US\$67,212 per hectare ( $s d$ US\$79,676). In comparison, we used data from our forest assessment, merchantable volumes, to estimate the average standing timber value at US\$3715 per hectare ( $n=85$, sd US\$1870).

We then examined the prevalence of NIPFs that generate revenue using their forested lands including tax breaks. Of 71 respondents, $30 \%$ generate income of any type, primarily from timber sales, grazing livestock, and hunting concessions. Contributions of these activities ranged from $0.5 \%$ of household income to $90 \%$, with a median value of $4 \%$. Only three landowners list contributions $>5 \%$ to household income. Alternatively, $79 \%$ do not actively manage their land. Six woodland owners $(2.4 \%)$ have a permanent conservation easement on some portions of their land, but most do not use, or are ineligible, for tax shelters. Twentythree percent have their forested land in North Carolina;s PUV program; forty-six percent are not enrolled and thirty-one percent are not aware if they are enrolled ("Don't know"). We estimated that, based on an 8.3 ha (20 acre) participation size threshold, over two-thirds with "Don't know" responses were not qualified to enroll. From this analysis of survey responses, it appears that approximately $70 \%$ of participants pay full property taxes on land assets without generating compensating income.
Of the 126 participants, $21 \%$ indicated active engagement in land markets and either have land for sale or are considering selling within 12 months. Of these, $80 \%$ have never sold land before, and only $5 \%$ have sold land $2009-2011$. The other $79 \%$ currently have no intentions of selling. Over $50 \%$ of participants do not track local real estate markets. We found that $27 \%$ of those actively managing their forest indicated willingness to sell, in comparison to $20 \%$ of those who do not manage.

When asked to list the importance of factors contributing to their decision to sell using a Likert-type scale ranging from 1, "Not Important," to 5, "Very Important," respondents $(n=7)$ ranked "Offer from a buyer too good to turn down" (average score 4.25), "Concern about ability to afford property taxes" (average score $4.0)$, "Development of nearby land reducing desirable rural character" (average score 3.8), and "Immediate need for cash" (average score 3.6) as primary concerns. Unimportant concerns included "Too much work to maintain the wooded land," "Tax credit from donating it to qualified nonprofit," and other minor concerns ("Other").

Our low response rate of $5.7 \%$ initially suggests the likelihood of self-selection bias, which raises concerns as to whether the attitudes and experiences of the sampled group are representative of the region's urban NIPFs as a whole. Bias of this type is difficult to compensate for statistically and reduces the degree of causal inference from the responses. More importantly, it could potentially call into question the findings from our revealed preference survey, namely that (1) the sample group was largely uninterested in selling and (2) valued their land intrinsically. However, a degree of confidence in the sample was substantiated when PCA analysis of woodland owner values identified a multidimensional response, and subsequently cluster analysis demonstrated a range of owner motivations.

\section{Principal components and cluster analysis of woodland owner attitudes}

Woodland owners exhibited a range of views regarding forests in general, which we interpreted using clustering methods. Participants ( $n=118,8$ excluded for incomplete responses) responded to a Likert-type scale ranging from 1, "Not Important," to 5, "Very Important" (Table 1). Principal components analysis indicated that two attitudinal factors (Table 2) categorized as 'cognitive' and 'affective' (Millar 1989, cited in Jorgensen and Stedman 2006) accounted for $72 \%$ of total response variance. Factorability of variables was confirmed by a Kaiser-Meyer-Olkin (KMO) value of 0.86 .

Cognitive and affective categories were interpreted from the component score coefficient matrix, which reflects correlations between factors and response variables. Cognitive attitudes leverage beliefs and perceptions to achieve specified outcomes for woodland owners, such as economic benefits of forest provisioning or building a generational legacy. Affective attitudes revolve around feelings and emotional aspects of forest benefits, such as aesthetics, life sustaining services, and biodiversity. Cognitive and affective constructs are not mutually exclusive and can interact in complex ways as reflected by spiritual and cultural/ historical component scores (for a more in-depth review of this literature see Jorgensen and Stedman 2006). 
Table 1. Example survey responses (percentage of answers) for the question: "Please rate your level of agreement with each of the following statements. I value wooded lands because: ...":

\begin{tabular}{|c|c|c|c|c|c|c|c|c|}
\hline \multirow[b]{3}{*}{ Responses } & \multicolumn{8}{|c|}{ Percent of Answers } \\
\hline & \multicolumn{3}{|c|}{$\begin{array}{c}\text { Not } \\
\text { Important }\end{array}$} & \multicolumn{2}{|c|}{$\begin{array}{c}\text { Very } \\
\text { Important }\end{array}$} & \multirow[b]{2}{*}{ N/A } & \multirow[b]{2}{*}{ Missing } & \multirow[b]{2}{*}{$\begin{array}{l}\text { Rating } \\
\text { Average }\end{array}$} \\
\hline & 1 & 2 & 3 & 4 & 5 & & & \\
\hline $\begin{array}{l}\text { A: I enjoy the forest scenery, sights, sounds, smells, } \\
\text { etc. }\end{array}$ & 1.1 & 1.1 & 6.7 & 10.1 & 77.5 & 3.4 & 1.1 & 4.67 \\
\hline $\begin{array}{l}\text { B: They provide timber, fisheries, minerals, or } \\
\text { tourism opportunities such as outfitting and guiding. }\end{array}$ & 11.8 & 4.7 & 9.4 & 9.4 & 52.9 & 11.8 & 11.8 & 3.99 \\
\hline $\begin{array}{l}\text { C: They provide a place for my favorite outdoor } \\
\text { recreation activities. }\end{array}$ & 10.3 & 10.3 & 16.1 & 12.6 & 41.4 & 9.2 & 10.3 & 3.71 \\
\hline $\begin{array}{l}\text { D: They help produce, preserve, clean, and renew air, } \\
\text { soil, and water. }\end{array}$ & 1.1 & 0.0 & 6.8 & 11.4 & 77.3 & 3.4 & 1.1 & 4.69 \\
\hline $\begin{array}{l}\text { E: They provide a variety of fish, wildlife, plant life, } \\
\text { etc. }\end{array}$ & 1.2 & 2.3 & 11.6 & 10.5 & 69.8 & 4.7 & 1.2 & 4.52 \\
\hline $\begin{array}{l}\text { F: They are sacred, religious, or spiritually special } \\
\text { places to me or I feel reverence and respect for nature } \\
\text { there. }\end{array}$ & 9.4 & 14.1 & 22.4 & 9.4 & 34.1 & 10.6 & 9.4 & 3.50 \\
\hline $\begin{array}{l}\text { G: They have places and things of natural and } \\
\text { human history that matter to me, others, or the } \\
\text { nation. }\end{array}$ & 8.1 & 5.8 & 14.0 & 16.3 & 47.7 & 8.1 & 8.1 & 3.97 \\
\hline $\begin{array}{l}\text { H: They make me feel better, physically and/or } \\
\text { mentally. }\end{array}$ & 4.5 & 5.7 & 13.6 & 12.5 & 60.2 & 3.4 & 4.5 & 4.22 \\
\hline $\begin{array}{l}\text { I: They are a place for me to continue and pass down } \\
\text { the wisdom and knowledge, traditions, and way of } \\
\text { life of my ancestors. }\end{array}$ & 12.8 & 8.1 & 19.8 & 10.5 & 33.7 & 15.1 & 12.8 & 3.52 \\
\hline
\end{tabular}

Table 2. Component score coefficient matrix. The dimensionality of woodland owners' attitudes about forest in general where reduced using principal component analysis in preparation for cluster analysis. We identified two attitudinal factors, interpreted as cognitive and affective, which accounted for $72 \%$ of total response variance.

\begin{tabular}{ccc}
\hline \hline & \multicolumn{2}{c}{ Factor } \\
\cline { 2 - 3 } Component & Cognitive & Affective \\
\hline aesthetic & -0.187 & 0.386 \\
economic & 0.308 & -0.113 \\
recreation & 0.134 & 0.055 \\
sustaining services & -0.191 & 0.395 \\
biodiversity & -0.088 & 0.299 \\
spirituality & 0.346 & -0.140 \\
cultural/historical & 0.285 & -0.066 \\
therapeutic & -0.002 & 0.214 \\
legacy & 0.396 & -0.200 \\
\hline
\end{tabular}

Component scores were then used to cluster landowners into the four nonhierarchical typologies indicated using the $\mathrm{k}$-means method in Figure 6. Type $1(n=11)$ held a wide range of values, but were more conservative in their responses, with tempered scores to all questions. Type $2(n=6)$ did not value forest for the responses listed and were indifferent or perhaps incidental woodland owners. Type 3 , the largest group, $(n=68)$ indicated a holistic perspective, valuing supporting and regulating services as well as the provisioning of timber (response B, see Fig. 7) as well as cultural aspects such as spiritual, historical, therapeutic, and legacy services (responses C, F-I). Type $4(n=33)$ focused on the ecosystem services provided by their forests, placing high values on habitat provisioning (A), biodiversity (E) and regulating services, such as the purification of water and air (D). This analysis reveals a range of utility preferences, rather than just those woodland owners who are vocal about landscape preservation and/or environmentalism. This typology improves our confidence that responses indeed represent a diverse range of woodland owners in the region.

\section{Willingness to sell models}

We constructed a regression tree model to understand the contribution of regional, local, and individual intrinsic and extrinsic woodland owner values in their decision to hold or sell in the immediate year (Fig. 3). Of the 86 landowners for which site-level ecological data were available, $24 \%$ (21) indicated a willingness to sell based on responses to survey questions "What is your vision for the wooded land twelve months from now?", "Is your land currently for sale?", and "Would you sell this land today if someone offered you the price you estimated."

Given the categorical response variable "willing to sell," we used a K-fold cross-validation method to select a final classification tree with an overall correct classification rate of $88 \%$ Kappa $=$ 0.6245 ). Figure 3 illustrates nonlinear interactions between variables that lead to the decision to sell or hold. This model accounted for $47.8 \%$ of overall variance in the data, with fit slightly lower in each of five folded data groups (average $\mathrm{R}^{2}=$ 0.474 for 10 subsets). Logistic regression models were also developed for this analysis but had nearly $20 \%$ lower model fit 
Fig. 6. Cluster analysis of participants $(n=118)$ responding to the question: I value wooded lands because... Four typologies emerged $(1,2,3$, and 4$)$ illustrating both the multidimensionality of woodland owner motivations and a range of utility preferences. Responses indicate values regarding aesthetics (A), economics (B), recreation (C), sustaining services (D), biodiversity (E), spirituality (F), cultural/historical $(G)$, therapeutic (H), and legacy (I).

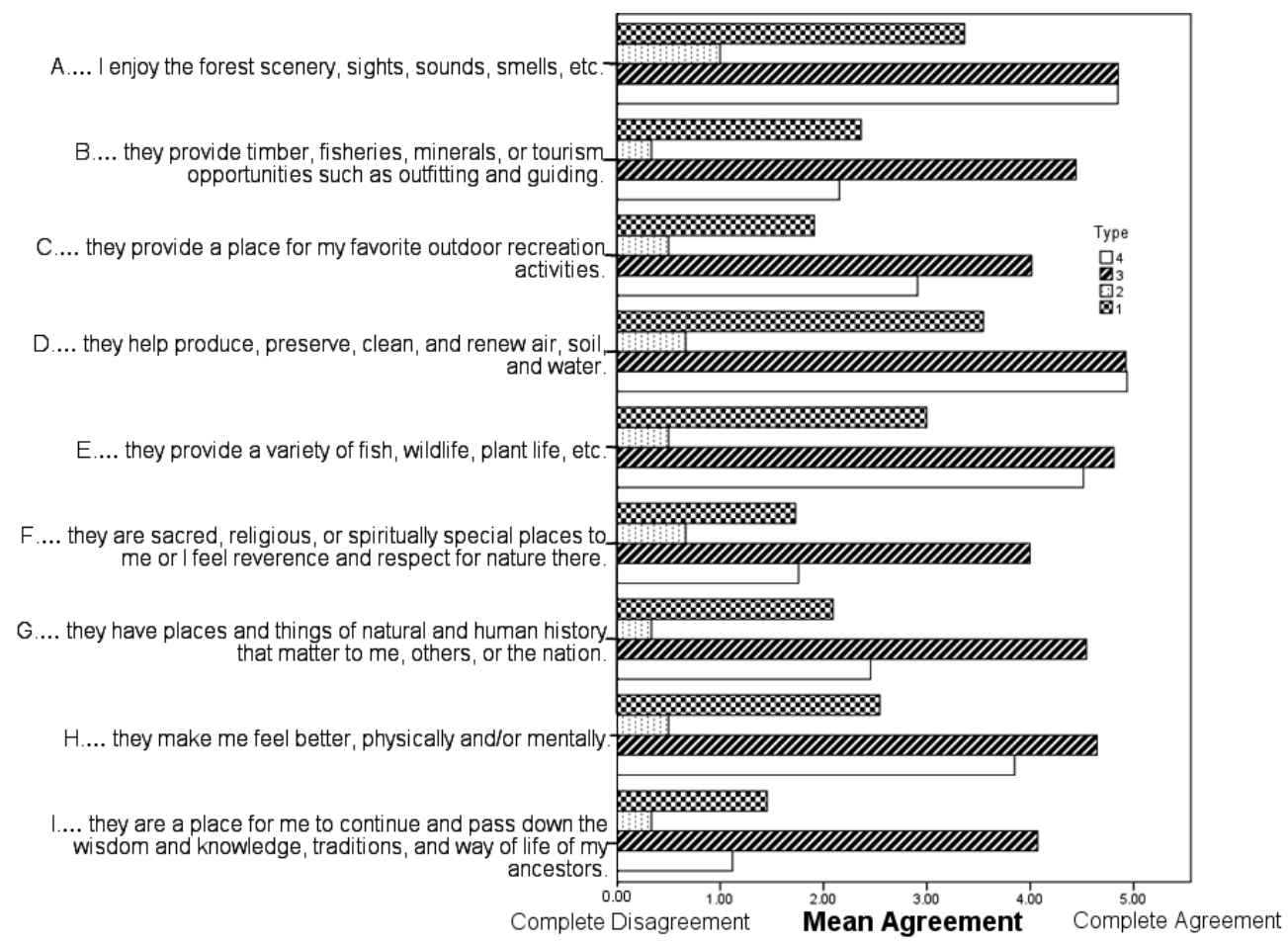

(maximum Nagelkerke $\mathrm{R}^{2}=0.283$ ) and $5 \%$ lower classification accuracy (correct classification rate $83.3 \%$, Kappa $=0.445$ ), and will not discussed further.

The 5 major predictors from the pool of 46 variables included sense of place attitudes about retaining vegetation, size of forest holdings, the degree of development pressure surrounding the site, frequency of visitation to the site, and owner's connectedness to nature. The degree of influence the variables exert on the model is illustrated in Figure 7. These predictors were uncorrelated (maximum $r<0.22$ ) with the exception of sense of place attitudes toward retaining native vegetation and connectedness to nature $(r=0.49)$. We also tested the relationship between owners' attitudes about retaining native vegetation and the ecological assets on their land, finding little explanation of variance $\left(\mathrm{R}^{2}<\right.$ 0.17 ) among the 15 ecological variables in the treatment.

The first split of the root node is based on woodland landowner "sense of place" attitudes toward retaining native vegetation, with factor values $>-0.687$ splitting the respondent group into 72 woodland owners with an $18 \%$ probability of being willing to sell, and factor values $<-0.687(n=14)$ with a $55 \%$ probability of being willing to sell. Higher factor values reflect positive site-level responses to three statements: "I like to keep my wooded land as natural as possible," "I don't like to disturb the natural vegetation on my wooded land," and "I like to have a lot of natural vegetation on my wooded land."
Fig. 7. The relative contribution of predictors indicating a willingness to sell measured by the $\mathrm{G}^{2}$ likelihood ratio test, a statistic commonly used to compare fits of nested models in categorical data. 'Development Pressure' is a spatially explicit variable (Fig. 1) generated using a gravity algorithm that serves as a proxy for the effects proximity to development exerts on undeveloped land. Development pressure is insinuated in feedbacks in which increased development increases predilection to sell by altering sense of place attitudes and visitation values toward forest.

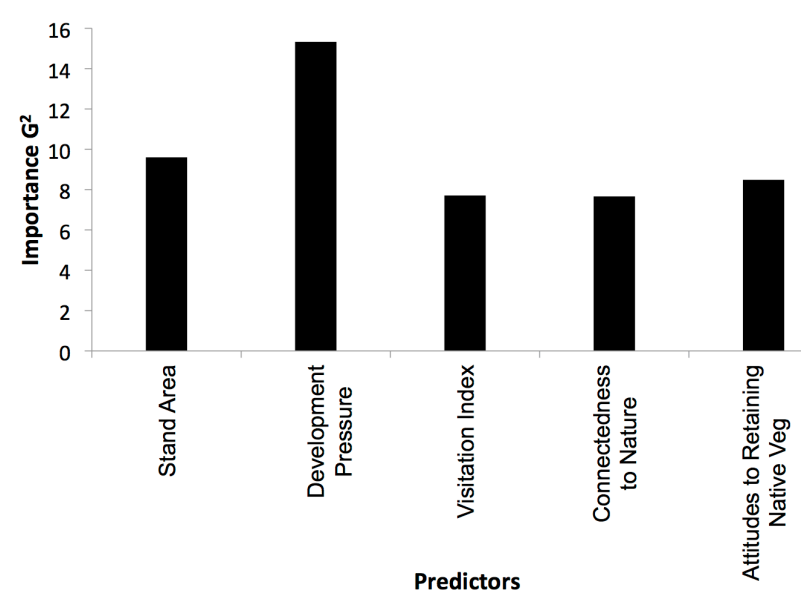


Woodland owners with positive attitude scores about retaining native vegetation were then split based on forest size, with owners with smaller sites $<13.5$ ha $(n=44)$ less likely to sell, forming a terminal node, and owners of larger forests sites more likely to sell $(n=28)$. The development pressure variable contributed most to the model as whole (Fig. 3). Development pressure was $>14.576$ among woodland owners with larger forest resulting in a $60 \%$ probability of being willing to sell. In areas with increased development pressure, owners with high rates of visitation including living on the property usually held onto land; low visitation usually indicated willingness to sell.

The 14 woodland owners with low vegetation attitudinal scores were split into 2 terminal nodes based on connectedness to nature factor values. Of these, a third of owners with low connectedness scores were likely to be willing to sell, whereas all woodland owners with higher connectedness scores were indicated as willing to sell. Five woodland owners with higher connectedness scores had an $88 \%$ probability of being willing to sell. Higher factor values for connectedness to nature represent positive responses to three statements generalized to all forest, not just the owners forest: "I feel like nature is a part of me," "I get greater satisfaction out of visiting nature than other areas," and "I find that a lot of my life is organized around enjoying nature in general." Interestingly, $88 \%$ of those who valued their connectedness to all of nature, yet also had low scores for retaining native vegetation on their land, exhibited a predilection to sell.

\section{DISCUSSION AND CONCLUSIONS}

Efforts to promote public health and sustainability in rapidly urbanizing regions are routinely impeded by our limited understanding of the complex social-ecological, multiscalar, and often conflicting factors that influence persistence of natural landscapes. Our results revealed the prevalence of smaller, persistent woodlands near and behind the urban frontier, which are characterized by the owners' reluctance to sell. The persistence of forests in these areas has resulted in an attractive mix of land covers and urban forest for which the city and region of Charlotte, North Carolina is recognized. Although the motivations of these urban woodland owners vary widely, our analysis of a sample of owners found that economic factors such as income generation from timber harvest and land concessions or tax breaks did not figure prominently in the decision to retain forests, at least in the short term.

Site-based ecological values, such as biomass, diversity, or presence of invasive plants, were also not found to influence predilection to sell. We had hypothesized that the woodland owner's biological assets, such as stand age, average DBH, variety of overstory species, or prevalence of charismatic Quercus species would influence their willingness to sell. Similarly, we thought that the presence of noxious invasive vines and shrubs such as Lonicera spp. may have proven a disincentive to forest persistence. Neither of these hypotheses were supported.

\section{Policy applications and tools}

Owners' decisions were characterized by a mix of feedback structures including sense of place values regarding the retention of native vegetation, the size of forest holdings, the relative connectedness of owners to nature, 'pressure' to develop as attributed to landscape context, and behavioral qualities, such has how often landowners visited their land. Given the lack of predictive significance in site-specific economic and ecological values, continued persistence for larger forest holdings are likely dependent on the relationship between sense of place attitudes, owner visitation, and development pressure. Given the region's paucity of policy tools to manage the growth of development, and thereby development pressure, the mosaic of land cover the region currently enjoys is far from secure.

Of the policy tools that are available, we estimate that less than $22 \%$ of current woodland landowners are eligible for PUV tax incentives in the region, as they own less than 20 acres of contiguous forest stand. Nationwide woodlands under 10 acres ( $\sim$ ha) are not sampled by the NWOS (U.S. Forest Service 2012a) and are therefore underrepresented in much of the national data. Policies, in this case, are unlikely to be configured for urban forest ownership patterns and are not designed to incentivize continued forest persistence. These results suggest that policies designed to promote woodlands in North Carolina, primarily through the PUV discount, are not relevant to urban woodland owners whose holdings are too small to meet current program guidelines. If supported by further research, these findings have important ramifications for the resilience of urban forest systems, as they point to the need to establish policies and programs that encourage conservation-minded management practices and tax incentives to the owners of small woodland holdings at the frontier of development.

\section{Pathways to development}

The use of classification trees graphically illustrates nonlinear and interactive pathways leading to a willingness to sell. The most direct path to urban woodland persistence exists among woodland owners with positive attitudes about retaining the native vegetation on their land and smaller forest holdings. These owners exhibit an $82 \%$ probability of being unwilling to sell. Conversely, the path exhibiting the highest probability of willingness to sell is among woodland owners with positive attitudes about retaining native vegetation (see Fig. 7), larger forest holdings, moderate-to-high development pressure, and who spend relatively little time on their land. These owners have a $90 \%$ chance of being willing to sell. If we examine the effect of forest size, woodland owners with similar attitude scores and larger holdings were five times more likely to sell and exhibit sensitivity to low levels of nearby development. The 5.45 ha size of holdings is likely associated to suitability thresholds for minimum sizes of development, a value that is loosely corroborated by a previous study of Cabarrus County, which found that new patches of development averaged 3.8 ha ( $s d 9.60$ ) between 1996 and 2006 (Meentemeyer et al. 2013). If this is the case, then owners may be dissuaded from selling smaller holdings because of low demand.

Larger forests may be in relatively greater demand, but willingness to sell is mediated by development pressure and attitudes toward retaining native vegetation. Development pressure's strong contribution to this model signals both the presence of a dynamic feedback loop, in which the presence of development attracts more development (Meentemeyer et al. 2013), and the identification of a 'tipping point' value of 14.58 indicating relatively low pressure levels may facilitate movement into alternative stable states, from 'forest' to 'development.'

By what process does development pressure affect landowners and attract more development? The increasing presence of neighboring development may change the way woodland owners' 
perceive their forests. The role of sense of place values and attitudes toward behavioral commitments to specific geographies is well established (Jorgensen and Stedman 2006, Brown and Raymond 2007) and highly contributory to this model. Using the revealed preference data, we tested the relationship between woodland sense of place values toward native vegetation and development pressure and found a weak negative correlation $(r$ $=-0.216$ ). Although beyond the immediate scope of our study, these results encourage longitudinal investigations that look at the role of development pressure over time and space and how the proximity of new development affects sense of place values and visitation.

This analysis also revealed the linkages between owners' attitudes about retaining native vegetation and both their propensity to either maintain or convert their forests. The lack of explanation of relationships $\left(\mathrm{R}^{2}<0.17\right)$ between biological assets and attitudes about retaining native vegetation is perhaps indicative of an uncoupling between woodland owners and the ecological assets on their lands and suggests that the high forest values reported (Table 1) may instead be conditioned by broader environmental contexts, societal norms, or experiences beyond their lands. The strength of this finding lends strong support for programs that sustain conservation through environmental education. This hypothesis should be further tested, perhaps with a stated preference survey, in contrast to our revealed preference survey.

Economic factors were also not predictive of willingness to sell. Although few (30\%) woodland owners generated income of any sort through sales of timber or nontimber products, or land concessions such as hunting or grazing, those that did showed no additional predilection to sell or keep their land. Similarly, total value of standing timber on their land did not contribute to the model. Forest and farmland owners in the region have access to a number of federal, state, and local incentive programs, each with a distinct set of criteria, which were not evaluated in this study. Few in our sample were enrolled in an incentive program, and those with PUV tax assessments showed no additional willingness to persist.

Conceptually, the spatially explicit approach we used has the potential to bridge macro- and microlevel analyses by linking outcomes (modeled response; i.e. the decision not to develop) and independent variables through a common unit, the woodland holding, from which growth patterns emerge. In fact, this approach reduces complexity by directly focusing on landowner level analysis of forest persistence to expose and quantify forestlandowner feedbacks.

We hypothesized the existence of additional feedback loops, in which losses of forest reduced sense of place values, which gradually caused woodland owners to visit their forest less often; this situation represents a combination of factors that we have shown to increase willingness to sell. In the event of the sale being manifested, the new development increased the pressure on remaining forest stands and the cycle is perpetuated.

\section{The distinct role of urban forest owners}

Is there a distinct urban nonindustrial private forest (U-NIPF) owners group that is different from NIPF owners as a whole? If the sampled group is indeed representative, then U-NIPF owners differ from their rural counterparts not only in their location, but also in their degree of education, size of forest holdings, and deemphasis of economic factors, such as timber revenues or land sales. Using NWOS data, Butler et al. (2007) reported that $41 \%$ of family forest owners nationwide have commercially harvested trees, and $23 \%$ were engaged in land markets. This contrasts with $30 \%$ and $21 \%$, respectively, among our participant U-NIPFs. Although differences exist between family forests defined by Butler and Leatherberry (2004) and the definitions of NIPF and U-NIPF used in this study, these groups are comparable.

Because of their prevalence at the urban frontier, U-NIPFs occupy a special role in the landscape by (1) buffering the advance of development, (2) acting as stewards to what is left of the region's functional ecosystems, and (3) producing substantial ecosystem services on which their city dwelling neighbors depend. The region's potential return to urban expansion rates observed from 1996-2006 will likely produce additional losses of forest stands that will perpetuate the development pressure cycle and will require municipalities to make substantial investments in storm water management infrastructure and other sorts of parallel engineering to replace urban ecosystem services lost with the forests.

Although many woodland owners have sold to developers or developed their own land, U-NIPFs are wealthier than previous generations and ascribe nonutilitarian, and often deeply personal and idiosyncratic, values to undeveloped land. Our work shows that these values often cause them to retain the land, despite paying property taxes on nonincome generating land, experiencing loss of rural character as neighbors sold or moved away, and enduring necessary changes in long-term management practices, e.g., controlled burning, caused by the proximity of new suburban neighbors. The substantial quantity of urban and exurban woodlands controlled by U-NIPFs, who value them for their cultural, spiritual, and intrinsic values, appears to contradict much of the utilitarian economic constructs and their traditional measurement mechanisms, such as highest and best use (HBU) principles. In future research, the use of the microlevel, woodland owner-centric approach presented may allow for quantification of the intrinsic dimensions of value ("missing markets") paid by woodland owners by accounting for the difference between land revenues, expenses, and foregone returns on investment that occur when landowners do not convert forests.

Over the next two decades, much of the current NIPF woodlands in the Charlotte region will change hands as the woodland-owner community ages. Do the heirs of these forest estates share the same sense of place values as the previous generation? If so, we may expect a broad resilience for forested systems as a whole. If not, however, it may be necessary for the region's counties, cities, and towns to promote proactive action, e.g., increasingly incentivized PUV policies, land purchases, urban forest restoration, to guarantee a mix of land covers that maintain regional character and stability in the provisioning and regulation of ecosystem services on which city dwellers depend.

Responses to this article can be read online at: http://www.ecologyandsociety.org/issues/responses. $\mathrm{php} / 6508$ 


\section{Acknowledgments:}

This work was financially supported by the NSF ULTRA-EX Program (Grant \#0948181), Renaissance Computing Institute (RENCI), USDA Forest Service, Open Space Protection Collaborative, North Carolina Wildlife Resources Commission, and the Z. Smith Reynolds Foundation. All research was approved under UNC-Charlotte IRB \#10-05-13. The following groups assisted from UNC-Charlotte: the UNC-Charlotte Center for Applied GIS (Wenwu Tang, Amy Stephens-Davis, Sanjay Lamsal, Wenpeng Fang, and Andrea Whitaker), the Charlotte Visualization Center (William Ribarsky, Zachary Wartell, Xiaoyu Wang), IDEAS Group (Chunhua Wang and Amos Gong), and Urban Institute (Vicki Bott, Kevin Hart, Bill McCoy, Carol Correll, Sara Gleave, and Jeff Michael). Our field group consisted of Christa Rodgers, Technician, (Mecklenburg County Park and Recreation), Chris Matthews (Mecklenburg County Park and Recreation), and Don F. Roach, II, Luke Tuschak, and Stephen F. Grayson (Division of Forest Resources). We thank the participants of the ULTRA-EX special session at the 2012 US IALE Annual Meeting in Rhode Island, as well as our community engagement partners for their assistance: D. Roy Alexander, Robert Bardon, Wendy Bell, Lauren Blackburn, Darrell Blackwelder, Debbie Bost, Tim Brown, Jim King, Davis Cable, Kacy Cook, Jeff Marcus, Christopher J. Daly, David Fogarty, Laura Fogo, Susan Fox, Lori Ivey, Eddie Reese, Roger Lamm, Matthew Barker, Robert C. Ward, Fitz Lee, Lee McLaren, Richard Melton, Susie Morris, Eric Muecke, Wib Owen, Ed Muire, Lori Quinn, Christa Rogers, Rick Roti, Dennis E. Testerman, Matthew Todd, Jeff Updike, Leslie N. Vanden Herik, Ken Vaughn, Jason Walser, Rebecca Yarbrough, Chris Matthews, Jacquelyn Wallace, and Randy Imler. We thank the anonymous reviewers whose suggestions greatly improved this manuscript.

\section{LITERATURE CITED}

Agarwal, C., G. M. Green, J. M. Grove, T. P. Evans, and C. M. Schweik. 2002. A review and assessment of land-use change models: dynamics of space, time, and human choice. General Technical Report NE-297. U.S. Forest Service, Northeastern Research Station, Newton Square, Pensylvania, USA. [online] URL: http:// www.treesearch.fs.fed.us/pubs/5027

Allen, T. F. H., and T. W. Hoekstra. 1993. Toward a unified ecology. Columbia University Press, New York, New York, USA.

American Forests. 2002. Projected environmental benefits of community tree planting: a multi-site urban forest project in Atlanta American Forests, Washington, D.C., USA.

American Forests, 2010. Urban ecosystem analysis, Mecklenburg County and the City of Charlotte, North Carolina: calculating the value of nature. American Forests, Washington, D.C., USA. [online] URL: http://www.charmeck.org/city/charlotte/epm/ Services/LandDevelopment/trees/TreeCommission/Documents/ Charlotte final.pdf

Anas, A., R. Arnott, and K. A. Small. 1998. Urban spatial structure. Journal of Economic Literature 36:1426-1464.

Angel, S., J. R. Parent, and D. Civco. 2007. Urban sprawl metrics: an analysis of global urban expansion using GIS. Pages in American Society for Photogrammetry and Remote Sensing (ASPRS) May 2007 Annual Conference: identifying geospatial solutions, Tampa, Florida. ASPRS, Bethesda, Maryland, USA. [online] URL: http://www.asprs.org/Conference-Proceedings/ Tampa-2007-ASPRS-Annual-Conference-Proceedings.html

BenDor, T., P. Berke, D. Salvesen, Y. Song, and N. Lenahan. 2011. Assessing local government capacity to manage and model military-induced growth in eastern North Carolina. Planning Practice and Research 26(5):531-553. http://dx.doi. org/10.1080/02697459.2011.626710

BenDor, T., and M. W. Doyle. 2009. Planning for ecosystem service markets. Journal of the American Planning Association 76 (1):59-72. http://dx.doi.org/10.1080/01944360903360100

Berke, P., D. Godschalk, E. Kaiser, and D. A. Rodriguez. 2006. Urban land use planning. 5th edition. University of Illinois Press, Urbana, Illinois, USA.

Bolund, P., and S. Hunhammar. 1999. Ecosystem services in urban areas. Ecological Economics 29:293-301. http://dx.doi. org/10.1016/S0921-8009(99)00013-0

Boraks, D. 2008. Town board endorses county park bonds, urges yes vote. Davidson News, 15 October. [online]. URL: http:// davidsonnews.net/blog/2008/10/15/town-board-endorses-countypark-bonds-urges-yes-vote/

Brown, D. G., K. M. Johnson, T. R. Loveland, and D. M. Theobald. 2005. Rural land-use trends in the conterminous United States, 1950-2000. Ecological Applications 15:1851-1863. http://dx.doi.org/10.1890/03-5220

Brown, G., and C. Raymond. 2007. The relationship between place attachment and landscape values: toward mapping place attachment. Applied geography 27(2):89-111. http://dx.doi. org/10.1016/j.apgeog.2006.11.002

Brown, G. G., P. Reed, and C. C.Harris. 2002. Testing a placebased theory for environmental evaluation: an Alaska case study. Applied Geography 22:49-76. http://dx.doi.org/10.1016/S0143-6228 (01)00019-4

Butler, B. J., and E. C. Leatherberry. 2004. Americas family forest owners. Journal of Forestry 102(7):4-14. [online] URL: http:// www.postcom.com/eco/sls.docs/USFS-Family $\% 20$ forests $\% 20$ article. pdf

Butler, B. J., M. Tyrrell, G. Feinberg, S. VanManen, L. Wiseman, and S. Wallinger. 2007. Understanding and reaching family forest owners: lessons from social marketing research. Journal of Forestry 105(7):348-357. [online] URL: http://old.interfacesouth. org/changing roles/files/05understandingandreaching.pdf

Campbell, H. S., and D. K. Monroe. 2007. Greenways and greenbacks: the impact of the Catawba Regional Trail on property values in Charlotte, North Carolina. Southeastern Geographer 47:118-137. http://dx.doi.org/10.1353/sgo.2007.0002

Centralina Council of Governments (CCOG). 2011a. HUD sustainable communities: regional planning initatives. Centralina Council of Governments, Charlotte, North Carolina, USA. [online] http://www.centralina.org/regional-planning/regionalplanning/hud-sustainable-communities/

Centralina Council of Governments (CCOG). 2011b. Region to plan for jobs and growth with \$4.9 Million sustainable communities grant (Press Release) Centralina Council of Governments, 
Charlotte, North Carolina, USA. [online] URL: http://www. centralinawdb.com/ccogworking/wp-content/uploads/2012/01/CCOGPress-Release-11-28-2011.pdf

Charlotte City Council. 2011. Preserving and enhancing our "city of trees" through establishment of a tree canopy goal " $50 \%$ in 2050 ."

Charlotte City Council, Charlotte, North Carolina, USA. [online] URL: http://charmeck.org/city/charlotte/cityclerk/councilrelated/ documents/agenda $\% 20$ attachments/07-23-2012\%20bus $\% 20$ meeting $/ 01 \%$ 2007-23-2012.pdf

Chesser, J. 2013. Carolinas growth update: urban changes, rural losses. UNC Charlotte Urban Institute, Charlotte, North Carolina, USA. [online] URL: http://plancharlotte.org/story/ urban-growth-rural-population-loss-nc-sc-2011

Chiesura, A. 2004. The role of urban parks for the sustainable city. Landscape and Urban Planning 68:129-138. http://dx.doi. org/10.1016/j.landurbplan.2003.08.003

Costanza, R., J. Cumberland, H. Daly, R. Goodland, and R. Norgaard. 1997. An introduction to ecological economics. CRC Press, Boca Raton, Florida, USA.

Cusimano, M. S., R. Bardsley, A. Ashton, and J. Hill. 2009. Greensboro, North Carolina tree canopy study. City of Greensboro, Greensboro, North Carolina, USA, and North Carolina State University Department of Forestry and Environmental Resource, [online] URL: http://www.greensboro-nc.gov/modules/showdocument. aspx?documentid $=3473$

Daily, G. C. 1997. Nature's services: societal dependence on natural resources. Island, Washington, D.C., USA.

Davidson, A. D., M. J. Hamilton, A. G. Boyer, J. H. Brown, and G. Ceballos. 2009. Multiple ecological pathways to extinction in mammals. Proceedings of the National Academy of Sciences 106 (26):10702-10705. http://dx.doi.org/10.1073/pnas.0901956106

DeFries, R. S., E. C. Ellis, F. S. Chapin, III, P. A. Matson, B. L. Turner, II, A. Agrawal, P. J. Crutzen, C. Field, P. Gleick, P. M. Kareiva, E. Lambin, D. Liverman, E. Ostrom, P. A. Sanchez, and J. Syvitski. 2012. Planetary opportunities: a social contract for global change science to contribute to a sustainable future. BioScience 62(6):603-606. http://dx.doi.org/10.1525/bio.2012.62.6.11

Dotzour, M. G., T. V. Grissom, C. H. Liu, and T. Pearson. 1990. Highest and best use: the evolving paradigm. Journal of Real Estate Research 5(1):17-32.

Ewing, R. H., R. Pendall, and D. D. T. Chen. 2002. Measuring sprawl and its impacts. Smart Growth America, Washington, D. C., USA.

Farber, S. C., R. Costanza, and M. A. Wilson. 2002. Economic and ecological concepts for valuing ecosystem services. Ecological Economics 41:375-392. http://dx.doi.org/10.1016/S0921-8009(02) $\underline{00088-5}$

Florida, R., T. Gulden, and C. Mellander. 2008. The rise of the mega-region. Cambridge Journal of Regions, Economy and Society 1(3)459-476. http://dx.doi.org/10.1093/cjres/rsn018

Fudenberg, D., and J. Tirole. 1983. Game theory. MIT Press, Cambridge, Massachusetts, USA.
Giddens, A. 1986. The constitution of society: outline of the theory of structuration. University of California Press: Berkeley, California, USA.

Glaeser, E. L., and J. E. Kohlhase. 2004. Cities, regions and the decline of transport costs. Papers in Regional Science 83:197-228. http://dx.doi.org/10.1007/s10110-003-0183-x

Glaeser, E. L., J. A. Scheinkman, and A. Shleifer. 1995. Economic growth in a cross-section of cities. Journal of Monetary Economics 36(1):117-143. http://dx.doi.org/10.1016/0304-3932(95)01206-2

Gluch, R. M., and M. K. Ridd. 2010. The V-I-S model: quantifying the urban environment. Pages 85-116 in T. Rashed and C. Jürgens, editors. Remote sensing of urban and suburban areas. Springer Netherlands, Houten, the Netherlands. http://dx. doi.org/10.1007/978-1-4020-4385-7 6

Graham, J., and I. Hanou. 2010. Metropolitan Nashville and Davidson County tree canopy assessment. Metro Tree Advisory Committee and Metropolitan Government of Nashville and Davidson County, Nashville, Tennessee, USA. [online] URL: http://www.nashville.gov/Public-Works/Community-Beautification/ Tree-Information/Inventory-and-Canopy-Assessment.aspx

Grove, J. M., and W. R. Burch, Jr. 1997. A social ecology approach and applications of urban ecosystem and landscape analyses: a case study of Baltimore, Maryland. Urban Ecosystems 1:259-275. http://dx.doi.org/10.1023/A:1018591931544

Hansen, A. J., R. L. Knight, J. M. Marzluff, S. Powell, K. Brown, P. H. Gude, and K. Jones. 2005. Effects of exurban development on biodiversity: patterns, mechanisms, and research needs Ecological Applications 15:1893-1905. http://dx.doi.org/10.1890/05-5221

Harris, T., S. Baldwin, and J. Siry. 2011. United States timberland markets: transactions, values and market research 2000-2010. Timber Mart-South, Athens, Georgia, USA. [online] URL: http://www.timbermart-south.com/pdf/US Timberland Markets TOC 2011-04.pdf

Havard, W. C. 1981. The distinctive south: fading or reviving? Pages 35-44 in C. N. Wilson, editor. Why the South will survive? University of Georgia Press, Athens, Georgia, USA.

Hein, C. L., A. S. Pike, J. F. Blanco, A. P. Covich, F. N. Scatena, C. P. Hawkins, and T. A. Crowl. 2011. Effects of coupled natural and anthropogenic factors on the community structure of diadromous fish and shrimp species in tropical island streams. Freshwater Biology 56(5):1002-1015. http://dx.doi.org/10.1111/ j.1365-2427.2010.02537.x

Holling, C. S., L. H. Gunderson, and D. Ludwig. 2002. In quest of a theory of adaptive change. Pages in L. H. Gunderson and C. S. Holling, editors. Panarchy: understanding transformations in systems of humans and nature. Island, Washington, D.C., USA.

Hotelling, H. 1947. "Letter to National Park Service." Reprinted in An economic study of the monetary evaluation of recreation in the national parks. U.S. Department of the Interior, National Park Service and Recreation Planning Division, Washington, D.C., USA.

IBM Corporation. 2012. SPSS statistics for Windows, version 21.0. IBM Corporation, Armonk, New York, USA. 
Irwin, E. G., C. Jayaprakash, and D. K. Munroe. 2009. Towards a comprehensive framework for modeling urban spatial dynamics. Landscape Ecology 24(9):1223-1236. http://dx.doi.org/10.1007/ s10980-009-9353-9

Isard, W. 1956. Location and space-economy: a general theory relating to industrial location, market areas, land use, trade, and urban structure. MIT Press, Cambridge, Massachusetts, USA.

Jorgensen, B. S., and R. C. Stedman. 2001. Sense of place as an attitude: lakeshore owners attitudes toward their properties. Journal of Environmental Psychology 21(3):233-248. http://dx.doi. org/10.1006/jevp.2001.0226

Jorgensen, B. S., and R. C. Stedman. 2006. A comparative analysis of predictors of sense of place dimensions: attachment to, dependence on, and identification with lakeshore properties. Journal of Environmental Management 79(3):316-327. http://dx. doi.org/10.1016/j.jenvman.2005.08.003

Lee, S., and R. G. Lathrop, Jr. 2005. Sub-pixel estimation of urban land cover components with linear mixture model analysis and Landsat Thematic Mapper imagery. International Journal of Remote Sensing 26(22):4885-4905. http://dx.doi.org/10.1080/01$\underline{431160500300222}$

Maestas, J. D., R. L. Knight, and W. C. Gilgert. 2003. Biodiversity across a rural land-use gradient. Conservation Biology 17 (5):1425-1434. http://dx.doi.org/10.1046/j.1523-1739.2003.02371. $\underline{\mathrm{X}}$

Majumdar, I., L. Teeter, and B. J. Butler. 2008. Characterizing family forest owners: a cluster analysis approach. Forest Science 54(2):176-184.

Mathis, M. L., A. A. Fawcett, and L. S. Konda. 2003. Valuing nature: a survey of the non-market valuation literature Houston Advanced Research Center, Houston, Texas, USA. [online] URL: http://files.harc.edu/Projects/Nature/ValuingNatureSurvey.pdf

McDonald, R. I., and D. L. Urban. 2006. Edge effects on species composition and exotic species abundance in the North Carolina Piedmont. Biological Invasions 8:1049-1060. http://dx.doi. org/10.1007/s10530-005-5227-5

McDonnell, M. J., and S. T. A. Pickett. 1990. Ecosystem structure and function along urban-rural gradients: an unexploited opportunity for ecology. Ecology 71(4):1232-1237. http://dx.doi. org/10.2307/1938259

Meentemeyer, R. K., W. Tang, M. A. Dorning, J. B. Vogler, N. J. Cunniffe, and D. A. Shoemaker. 2013. FUTURES: Multilevel simulations of emerging urban-rural landscape structure using a stochastic patch-growing algorithm. Annals of the Association of American Geographers 103(4):785-807. http://dx.doi. org/10.1080/00045608.2012.707591

Michaelsen, J., D. S. Schimel, M. A. Friedl, F. W. Davis, and R. C. Dubayah. 1994. Regression tree analysis of satellite and terrain data to guide vegetation sampling and surveys. Journal of Vegetation Science 5(5):673-686. http://dx.doi.org/10.2307/3235882

Millar, M. G. 1989. The effects of affective-cognitive consistency and thought on the attitude-behavior relation. Journal of Experimental Social Psychology 25(2):189-202. http://dx.doi. org/10.1016/0022-1031(89)90012-7
Millennium Ecosystem Assessment (MEA). 2005. Ecosystems and human wellbeing: biodiversity synthesis. World Resources Institute: Washington, D.C., USA. [online] URL: http://www. unep.org/maweb/documents/document.354.aspx.pdf

Naveh, Z. 2000. The total human ecosystem: integrating ecology and economics. BioScience 50:357-361. http://dx.doi. org/10.1641/0006-3568(2000)050[0357:TTHEIE]2.3.CO;2

North Carolina State Demographics Office. 2011. Population estimates and projections North Carolina State Demographics Office, Raleigh, North Carolina, USA [online] URL: http://www. osbm.state.nc.us/ncosbm/facts_and_figures/socioeconomic data/ population estimates.shtm

North Carolina Industries of the Future (NCIOF) and North Carolina Forestry Association (NCFA). 2003. The state of our forest products industry North Carolina Industries of the Future and North Carolina Forestry Association, Raleigh, North Carolina, USA. [online] URL: http://search.ncforestry.org/ WEBPAGES/PUBS $\% 20 A N D \% 20$ VIDEOS/STATEOFFORESTPRODUCTS.pdf

North Carolina Department of Revenue. 2014. Present-use value program guide [online]. North Carolina Department of Revenue, Raleigh, North Carolina, USA. [online] URL: http://www.dor. state.nc.us/publications/puv guide.pdf

National Science Foundation (NSF). 2003. Complex environmental systems: synthesis for Earth, life, and society in the 21 st century. National Science Foundation, Washington, D.C., USA. [online] URL: http://www.nsf.gov/geo/ere/ereweb/ac-ere/ acere synthesis rpt full.pdf

Ostrom, E. 1990. Governing the commons: the evolution of institutions for collective action. Cambridge University Press, Cambridge, UK. http://dx.doi.org/10.1017/CBO9780511807763

Ott, S. H., and D. C. Read. 2006. The effect of growth management strategies: adequate public facilities ordinances and impact fees. A review of existing research University of North Carolina, Charlotte, North Carolina, USA.

Pattee, H. H., editor. 1973. Hierarchy theory: the challenge of complex systems. George Braziller, New York, New York, USA.

Pickett, S. T. A., J. W. R. Burch, Jr., S. E. Dalton, T. W. Foresman, J. M. Grove, and R. Rowntree. 1997. A conceptual framework for the study of human ecosystems in urban areas. Urban Ecosystems 1:185-199. http://dx.doi.org/10.1023/A:1018531712889

Pickett, S. T. A., M. L. Cadenasso, J. M. Grove, C. G. Boone, P. M. Groffman, E. Irwin, S. S. Kaushal, V. Marshall, B. P. McGrath, C. H. Nilon, R. V. Pouyat, K. Szlavecz, A. Troy, and P. Warren. 2011. Urban ecological systems: scientific foundations and a decade of progress. Journal of Environmental Management 92 (3):331-362. http://dx.doi.org/10.1016/j.jenvman.2010.08.022

Polasky, S., E. Nelson, E. Londsdorf, P. Fackler, and A. Starfield. 2005. Conserving species in a working landscape: land use with biological and economic objectives. Ecological Applications 15:1387-1401. http://dx.doi.org/10.1890/03-5423 
Pred, A. 1984. Place as historically contingent process: structuration and the time-geography of becoming places. Annals of the Association of American Geographers 74:279-297. http://dx. doi.org/10.1111/j.1467-8306.1984.tb01453.x

Radeloff, V. C., R. B. Hammer, and S. I. Stewart. 2005. Rural and suburban sprawl in the U.S. Midwest from 1940 to 2000 and its relation to forest fragmentation. Conservation Biology 19:793-805. http://dx.doi.org/10.1111/j.1523-1739.2005.00387.x

Regional Plan Association. 2012. America 2050 Megaregions Regional Plan Association, New York, New York, USA. [online] URL: http://www.america2050.org/maps/

Salvatore, D. 2008. Microeconomics: theory and applications. Oxford University Press, Oxford, UK.

Sarle, W. S. 1983. SAS technical report A-108: cubic clustering criterion. SAS Institute, Cary, North Carolina, USA.

SAS Institute. 2012. JMP Version 10.0.0. SAS Institute, Cary, North Carolina, USA.

Schaldach, R., and J. A. Priess. 2008. Integrated models of the land system: a review of modelling approaches on the regional to global scale. Living Reviews in Landscape Research 2:1. http://dx. doi.org/10.12942/1rlr-2008-1

Scoones, I. 1999. New ecology and the social sciences: what prospects for a fruitful engagement? Annual Review of Anthropology 28(1):479-507. http://dx.doi.org/10.1146/annurev. anthro.28.1.479

Singh, K. K., J. B. Vogler, D. A. Shoemaker, and R. K. Meentemeyer. 2012. LiDAR-Landsat data fusion for large-area assessment of urban land cover: balancing spatial resolution, data volume and mapping accuracy. ISPRS Journal of Photogrammetry and Remote Sensing 74:110-121. http://dx.doi.org/10.1016/j. isprsjprs.2012.09.009

Stedman, R. C. 2003. Sense of place and forest science: toward a program of quantitative research. Forest Science 49:822-829. [online] URL: http://tot.unm.edu/documents/Stedman2003 SoP ForSci. pdf

Sustain Charlotte. 2010. Charlotte 2030: a sustainable vision for our region Sustain Charlotte, Charlotte, North Carolina, USA. [online] URL: http://www.sustaincharlotte.org/images/Charlotte 2030 A Sustainable Vision - Low Res.pdf

Tyrväinen, L., K. Mäkinen, and J. Schipperijn. 2007. Tools for mapping social values of urban woodlands and other green areas. Landscape and Urban Planning 79:5-19. http://dx.doi. org/10.1016/j.landurbplan.2006.03.003

United States Forest Service. 1996. Timber appraisal handbook (Forest Service Handbook FSH-2409.12). U.S. Forest Service, Washington, D.C., USA.

United States Forest Service. 2012a. The forest inventory and analysis database: database description and users manual version 5.1 for phase 2 U.S. Forest Service, Arlington, Virginia, USA. [online] URL: http://www.fia.fs.fed.us/library/database-documentation/ current/ver5.1.4/FIADB user manual 5-1-4 p2 11 2012.pdf

United States Forest Service. 2012b. National woodland owner survey U.S. Forest Service, Forest Service, Forest Inventory and
Analysis National Program, Arlington, Virginia, USA. [online] URL: http://www.fia.fs.fed.us/nwos/

UNC Charlotte Urban Institute. 2013. Charlotte population growth: a clearer picture UNC Charlotte Urban Institute, Charlotte, North Carolina, USA. [online] http://ui.uncc.edu/ display/charlotte-region-population-growth-census-tract

United Nations. 2005. World urbanization prospects: the 2005 revision. United Nations Population Division, New York, New York, USA. [online] URL: http://www.un.org/esa/population/ publications/WUP2005/2005wup.htm

United Nations. 2007. The state of the world population 2007 : unleashing the potential for urban growth. United Nations Population Fund, New York, New York, USA.

United Nations, European Commission, International Monetary Fund, Organisation for Economic Co-operation and Development, and World Bank. 2005. Handbook of national accounting: integrated environmental and economic accounting 2003. Series F: studies in methods. No.61. United Nations, New York, New York, USA. [online] URL: http://unstats.un.org/unsd/ envaccounting/seea2003.pdf

Urban Land Institute. 2010. Lake Norman area, Charlotte, North Carolina: strategy for economic growth. Urban Land Institute, Washington, D.C., USA.

Urban Land Institute. 2011. Charlotte, North Carolina: reenergizing, repositioning, and ensuring the long-term viability of independence boulevard. A ULI Daniel Rose Fellowship program city study visit report. Urban Land Institute, Daniel Rose Center for Public Leadership in Land Use, Washington, D.C., USA.

Wang, C., J.-C. Thill, and R. K. Meentemeyer. 2012. Estimating the demand for public open space: evidence from North Carolina municipalities. Papers in Regional Science 91(1):219-232. http:// dx.doi.org/10.1111/j.1435-5957.2011.00372.x

Wang, K., and M. L. Wolverton. 2002. Real estate valuation theory. Springer, New York, New York, USA. http://dx.doi. org/10.1007/978-1-4615-0909-7

Warren, W. A. 2005. Hierarchy theory in sociology, ecology, and resource management: a conceptual model for natural resource or environmental sociology and socioecological systems. Society and Natural Resources 18:447-466. http://dx.doi. org/10.1080/08941920590924828

Westervelt, J., T. BenDor, and J. Sexton. 2011. A technique for rapidly assessing regional scale urban growth. Environment and Planning B: Planning and Design 38(1):61-81. http://dx.doi. org/10.1068/b36029

Williams, D. R., and J. J. Vaske. 2003. The measurement of place attachment: validity and generalization of a psychometric approach. Forest Science 49:830-840. [online] URL: http://www. wsl.ch/personal homepages/hunziker/teaching/download mat/ Williams Vaske 2003.pdf

Zipperer, W. C., J. Wu, R. V. Pouyat, and S. T. A. Pickett. 2000. The application of ecological principles to urban and urbanizing landscapes. Ecological Applications 10:685-688. http://dx.doi. org/10.1890/1051-0761(2000)010[0685:TAOEPT]2.0.CO;2 


\section{Appendix A: Variables Considered in Decision Tree Analysis}

\begin{tabular}{|c|c|c|c|}
\hline Label & Description & Units/Values/Notes & Base Data Source \\
\hline ALL SV RICHNESS & $\begin{array}{l}\text { Combined native and non-native woody stem shrub } \\
\text { and vine species }\end{array}$ & Count, species per stand & Ecological Field Data \\
\hline ALL TREE RiChNESS & Richness, overstory and understory tree species & Count, species per stand & Ecological Field Data \\
\hline AVERAGE AGE & Average age of stand & Years & Ecological Field Data \\
\hline AVERAGE DBH & Average DBH all overstory tree species & Inches $\dagger$ & Ecological Field Data \\
\hline BIOMASS & Dimensional weight in tons & U. S. Tons $\dagger$ & Ecological Field Data \\
\hline MAXIMUM DBH & Maximum $\mathrm{DBH}$ at site & Inches $†$ & Ecological Field Data \\
\hline NN RICHNESS & $\begin{array}{l}\text { Non-native woody stem shrub and vine species } \\
\text { richness }\end{array}$ & Count, species per stand & Ecological Field Data \\
\hline NO. COVER TyPES & Number of cover types & Count per stand & Ecological Field Data \\
\hline NSV RICHNESS & Native shrub and vine richness & Count, species per stand & Ecological Field Data \\
\hline OAKINESS & Gradient Quercus to Pinus species abundance & $\begin{array}{l}\text { Factor Score Principal } \\
\text { Component 2, } \\
\text { Dimensionless }\end{array}$ & $\begin{array}{l}\text { Ecological Field Data/Land Cover } \\
\text { Mapping }\end{array}$ \\
\hline OVERSTORY TREE RICHNESS & Overstory tree richness & Count, species per stand & Ecological Field Data \\
\hline REGENERATION & Forest regeneration type & $\begin{array}{l}1=\text { Natural } \\
2=\text { Plantation }\end{array}$ & Ecological Field Data \\
\hline TOTAL VALUE & Market value as of $12 / 2011$ & USD (\$) & Ecological Field Data \\
\hline TOTAL STEMS & Number of trees $>12.7 \mathrm{~cm} \mathrm{DBH}$ & Count & Ecological Field Data \\
\hline TOTAL FOREST AREA & Combined forest area per participant & Hectare & Ecological Field Data \\
\hline AGE & Age of woodland owner & Years & Revealed Preference Survey \\
\hline AESTHETIC & $\begin{array}{l}\text { Q35A. I value wooded lands because...I enjoy } \\
\text { scenery, sights, smells, etc. }\end{array}$ & $\begin{array}{l}\text { Likert-type scale (even } \\
\text { interval } 1-5, \mathrm{~N} / \mathrm{A})\end{array}$ & Revealed Preference Survey \\
\hline ATTACHMENT & $\begin{array}{l}\text { Q34: How important is your attachment to your } \\
\text { wooded lands? }\end{array}$ & $\begin{array}{l}\text { Likert-type scale (even } \\
\text { interval } 1-5, N / A)\end{array}$ & Revealed Preference Survey \\
\hline BIODIVERSITY & $\begin{array}{l}\text { Q35E. I value wooded lands because... they provide } \\
\text { a variety of fish, wildlife, plant life, etc. }\end{array}$ & $\begin{array}{l}\text { Likert-type scale (even } \\
\text { interval } 1-5, \mathrm{~N} / \mathrm{A})\end{array}$ & Revealed Preference Survey \\
\hline
\end{tabular}




\begin{tabular}{|c|c|c|c|}
\hline Label & Description & Units/Values/Notes & Base Data Source \\
\hline CONCERNS: "FREEDOM" & $\begin{array}{l}\text { Q24."How concerned are you about issues that may } \\
\text { affect your use and enjoyment of your wooded } \\
\text { land?" }\end{array}$ & $\begin{array}{l}\text { Factor Score Principal } \\
\text { Component } 1 \\
\text { Dimensionless }\end{array}$ & Revealed Preference Survey \\
\hline CONCERNS: "STABILITY" & $\begin{array}{l}\text { Q24. "How concerned are you about issues that may } \\
\text { affect your use and enjoyment of your wooded } \\
\text { land?" }\end{array}$ & $\begin{array}{l}\text { Factor Score Principal } \\
\text { Component } 2, \\
\text { Dimensionless }\end{array}$ & Revealed Preference Survey \\
\hline CONNECTION TO NATURE & $\begin{array}{l}\text { Q 36. Rate level of agreement: "Nature is part of } \\
\text { me", "I get greater satisfaction visiting nature...", } \\
\text { "...my life organized around enjoying nature..." }\end{array}$ & $\begin{array}{l}\text { Factor Score Principal } \\
\text { Component } 1 \\
\text { Dimensionless }\end{array}$ & Revealed Preference Survey \\
\hline ECONOMIC & $\begin{array}{l}\text { Q35B. I value wooded lands because...they provide } \\
\text { timber, fisheries, minerals, or tourism opportunities, } \\
\text { such as outfitting and guiding. }\end{array}$ & $\begin{array}{l}\text { Likert-type scale (even } \\
\text { interval 1-5, N/A) }\end{array}$ & Revealed Preference Survey \\
\hline HISTORICAL & $\begin{array}{l}\text { Q35G. I value wooded lands because... they have } \\
\text { places and things of natural and human history } \\
\text { that matter to me, others, or the nation. }\end{array}$ & $\begin{array}{l}\text { Likert-type scale (even } \\
\text { interval 1-5, N/A) }\end{array}$ & Revealed Preference Survey \\
\hline INCOME & $\begin{array}{l}\text { Q45. "What was your household's annual income } \\
\text { for 2010?" }\end{array}$ & Ordinal Categories 1-8 & Revealed Preference Survey \\
\hline INVESTMENT & Q8D. "Hold it as an investment? & $\begin{array}{l}0=\text { No } \\
1=\text { Yes }\end{array}$ & Revealed Preference Survey \\
\hline LAND ViSITATION INDEX & $\begin{array}{l}\text { Q10. "Over the past } 12 \text { months, about how many } \\
\text { days have you } \bullet \text { been on this wooded land? • seen } \\
\text { this wooded land?" }\end{array}$ & $\begin{array}{l}\text { On }=1 \text { per day } \\
\text { Seen }=0.5 \text { per day } \\
\text { Living on land }=1.5 \text { per day } \\
\text { Max score }=547\end{array}$ & Revealed Preference Survey \\
\hline LEGACY & $\begin{array}{l}\text { Q35I. I value wooded lands because... they are a } \\
\text { place for me to continue and pass down the wisdom } \\
\text { and knowledge, traditions, and way of life of my } \\
\text { ancestors. }\end{array}$ & $\begin{array}{l}\text { Likert-type scale (even } \\
\text { interval 1-5, N/A) }\end{array}$ & Revealed Preference Survey \\
\hline LIFE SUPPORT & $\begin{array}{l}\text { Q35D. I value wooded lands because...they help } \\
\text { produce, preserve, clean, and renew air, soil, and } \\
\text { water. }\end{array}$ & $\begin{array}{l}\text { Likert-type scale (even } \\
\text { interval 1-5, N/A) }\end{array}$ & Revealed Preference Survey \\
\hline LOSS OF RURAL CHARACTER & $\begin{array}{l}\text { Q25. "In your opinion, how soon will the area near } \\
\text { your wooded land lose its rural character due to } \\
\text { development?" }\end{array}$ & Ordinal Categories 1-8 & Revealed Preference Survey \\
\hline MANAGEMENT & $\begin{array}{l}\text { Aggregate:Q9. What management activities have } \\
\text { been conducted on your wooded land with the last } \\
\text { five years? }\end{array}$ & $\begin{array}{l}\text { Yes }=\text { Actively managed } \\
\text { No }=\text { Passive management }\end{array}$ & Revealed Preference Survey \\
\hline Present Use Value & Q15. "Is your land in the State's Present-Use Value & $0=$ No & Revealed Preference Survey \\
\hline
\end{tabular}




\begin{tabular}{|c|c|c|c|}
\hline Label & Description & Units/Values/Notes & Base Data Source \\
\hline & Program" & $\begin{array}{l}1=\text { Yes } \\
2=\text { Don't know/Unsure }\end{array}$ & \\
\hline RECREATION & $\begin{array}{l}\text { Q35C. I value wooded lands because...they provide } \\
\text { a place for my favorite outdoor recreation activities. }\end{array}$ & $\begin{array}{l}\text { Likert-type scale (even } \\
\text { interval } 1-5, \mathrm{~N} / \mathrm{A})\end{array}$ & Revealed Preference Survey \\
\hline REVENUE & Q8E. "Generate income from it?" & $\begin{array}{l}0=\text { No } \\
1=\text { Yes }\end{array}$ & Revealed Preference Survey \\
\hline SENSE OF PLACE: ATTACHMENT & $\begin{array}{l}\text { Q37. Rate level of agreement: "I feel relaxed on my } \\
\text { wooded land", "I feel happiest when I'm on my } \\
\text { wooded land", "My wooded land is my favorite } \\
\text { place..." }\end{array}$ & $\begin{array}{l}\text { Factor Score Principal } \\
\text { Component } 1, \\
\text { Dimensionless }\end{array}$ & Revealed Preference Survey \\
\hline $\begin{array}{l}\text { SENSE OF PLACE: ATtTITUDES } \\
\text { ABOUT DEVELOPMENT }\end{array}$ & $\begin{array}{l}\text { Q37. Rate level of agreement: "Too much } \\
\text { development near my wooded land will harm } \\
\text { wildlife habitat", "Too much development near my } \\
\text { wooded land will harm the natural character...", } \\
\text { "Too much development near my wooded land will } \\
\text { make the area less scenic" }\end{array}$ & $\begin{array}{l}\text { Factor Score Principal } \\
\text { Component } 1, \\
\text { Dimensionless }\end{array}$ & Revealed Preference Survey \\
\hline $\begin{array}{l}\text { SENSE OF PlaCE: AtTITUdeS } \\
\text { ABOUt RETAINING NATIVE } \\
\text { VeGETATION }\end{array}$ & $\begin{array}{l}\text { Q37. Rate level of agreement: "I like to keep my } \\
\text { wooded land as natural as possible", "I don't like to } \\
\text { disturb native vegetation on my wooded land", "I } \\
\text { like to have a lot of natural vegetation on my } \\
\text { wooded land" }\end{array}$ & $\begin{array}{l}\text { Factor Score Principal } \\
\text { Component } 1 \text {, } \\
\text { Dimensionless; negative } \\
\text { worded items inversely } \\
\text { coded }\end{array}$ & Revealed Preference Survey \\
\hline $\begin{array}{l}\text { SENSE OF PLACE: ATTITUDE S } \\
\text { ABOUT WOODLAND }\end{array}$ & $\begin{array}{l}\text { Q37. Rate level of agreement: "The wooded land is } \\
\text { the most important reason for owning and visiting } \\
\text { my property", "Being near the woods is the best } \\
\text { thing about my property", "The property would still } \\
\text { mean a lot to me even if it were not wooded" }\end{array}$ & $\begin{array}{l}\text { Factor Score Principal } \\
\text { Component } 1 \text {, } \\
\text { Dimensionless; negative } \\
\text { worded items inversely } \\
\text { coded }\end{array}$ & Revealed Preference Survey \\
\hline SENSE OF Place: DePENDENCy & $\begin{array}{l}\text { Q37. Rate level of agreement: "My wooded land is } \\
\text { the best place for doing the things I enjoy most", } \\
\text { "...no other place can compare to my wooded land", } \\
\text { "My wooded land is not a good place to do the } \\
\text { things I like most", "...there are better places to be } \\
\text { than on my wooded land" }\end{array}$ & $\begin{array}{l}\text { Factor Score Principal } \\
\text { Component } 1 \text {, } \\
\text { Dimensionless; negative } \\
\text { worded items inversely } \\
\text { coded }\end{array}$ & Revealed Preference Survey \\
\hline SENSE OF Place: IdENTITy & $\begin{array}{l}\text { Q37. Rate level of agreement: "my wooded land a } \\
\text { reflection of me", "wooded land says very little } \\
\text { about who I am", "I can really be myself on my } \\
\text { wooded land." }\end{array}$ & $\begin{array}{l}\text { Factor Score Principal } \\
\text { Component } 1, \\
\text { Dimensionless; negative } \\
\text { worded items inversely } \\
\text { coded } \$\end{array}$ & Revealed Preference Survey \\
\hline SPIRITUAL & Q35F. I value wooded lands because... they are & Likert-type scale (even & Revealed Preference Survey \\
\hline
\end{tabular}




\begin{tabular}{|c|c|c|c|}
\hline Label & Description & Units/Values/Notes & Base Data Source \\
\hline & $\begin{array}{l}\text { sacred, religious, or spiritually special places to me } \\
\text { or I feel reverence and respect for nature there. }\end{array}$ & interval 1-5, N/A) & \\
\hline TENURE & Years of ownership & Years & Revealed Preference Survey \\
\hline THERAPEUTIC & $\begin{array}{l}\text { Q35H. I value wooded lands because... they make } \\
\text { me feel better, physically and/or mentally. }\end{array}$ & $\begin{array}{l}\text { Likert-type scale (even } \\
\text { interval } 1-5, \mathrm{~N} / \mathrm{A})\end{array}$ & Revealed Preference Survey \\
\hline WiLLING TO SELL & $\begin{array}{l}\text { Aggregate: } \\
\text { Q19. What is "your vision for the wooded land } \\
\text { twelve months from now?" } \\
\text { Q26. "Is your land currently for sale?" } \\
\text { Q33. "Would you sell this land today if someone } \\
\text { offered you the price you estimated..." }\end{array}$ & $\begin{array}{l}0=\mathrm{No} \\
1=\text { Yes }\end{array}$ & Revealed Preference Survey \\
\hline CANOPY & Relative canopy coverage per stand & $\begin{array}{l}0=\text { None }(\text { clear cut }) \\
1=\text { Partial } \\
2=\text { Full }\end{array}$ & Remote Sensing \\
\hline DEVELOPMENT PRESSURE & "Pressure" development 2011: see equation (1). & $\begin{array}{l}\text { Dimensionless, } 2 \mathrm{~km}^{2} \\
\text { window centered on stand }\end{array}$ & Remote Sensing/Land Cover Mapping \\
\hline Distance To CBD & $\begin{array}{l}\text { Minimum Euclidean distance to Charlotte's central } \\
\text { business district }\end{array}$ & Meters & Remote Sensing/Land Cover Mapping \\
\hline FARM PRESSURE & "Pressure" farms 2011: see equation (1). & $\begin{array}{l}\text { Dimensionless, } 2 \mathrm{~km}^{2} \\
\text { window centered on stand }\end{array}$ & Remote Sensing/Land Cover Mapping \\
\hline MOMENTUM 1996 TO 2006 & $\begin{array}{l}\text { "Pressure" new development 1996-2006: see } \\
\text { equation (1). }\end{array}$ & $\begin{array}{l}\text { Dimensionless, } 2 \mathrm{~km}^{2} \\
\text { window centered on stand }\end{array}$ & Remote Sensing/Land Cover Mapping \\
\hline MOMENTUM 2006 TO 2011 & $\begin{array}{l}\text { "Pressure" new development 2006-2011: see } \\
\text { equation (1). }\end{array}$ & $\begin{array}{l}\text { Dimensionless, } 2 \mathrm{~km}^{2} \\
\text { window centered on stand }\end{array}$ & Remote Sensing/Land Cover Mapping \\
\hline MOMENTUM 1996 TO 2011 & $\begin{array}{l}\text { "Pressure" new development 1996-2011: see } \\
\text { equation (1). }\end{array}$ & $\begin{array}{l}\text { Dimensionless, } 2 \mathrm{~km}^{2} \\
\text { window centered on stand }\end{array}$ & Remote Sensing/Land Cover Mapping \\
\hline
\end{tabular}

$\dagger$ Units in English as specified by USDA Forest Service (1996) protocol.

† Jorgenson and Stedman, 2006 